\title{
Enhanced stress tolerance in transformed Ajuga bracteosa Wall. ex Benth. regenerants by upregulated gene expression of metabolic pathways
}

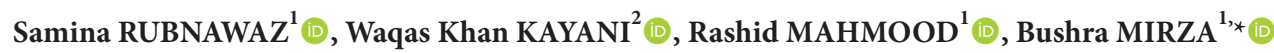 \\ ${ }^{1}$ Department of Biochemistry, Faculty of Biological Sciences, Quaid-i-Azam University, İslamabad, Pakistan \\ ${ }^{2}$ Department of Plant Breeding, Swedish University of Agricultural Sciences, Alnarp, Sweden
}

\begin{abstract}
The rol oncogenes of Agrobacterium rhizogenes enhance the production of medicinally important compounds in plants and provide a first barrier against the overproduction of reactive oxygen species during biotic and abiotic stress. This study was designed to evaluate the expression of genes involved in biosynthetic pathways and their impact on metabolic contents and environmental stress tolerance in regenerated Ajuga bracteosa Wall. ex Benth. After successful transformation, real-time quantitative PCR confirmed the increased expression (1.94-6.59-fold) of HMGR, HDS, FDS, PAL, and TTG1 genes in transgenic lines. Furthermore, GC-MS coupled with principal component analysis revealed diverse concentrations of 97 metabolites in A. bracteosa. Transgenic lines showed greater survival under multiple stresses. This was revealed by significant chlorophyll content $\left(8.13-21 \mu \mathrm{moles} / \mathrm{m}^{2}\right)$, higher quantum efficiency of PSII $\left(F_{v} / F_{\mathrm{m}}\right)$, and the performance index $\left(\mathrm{PI}_{\mathrm{abs}}\right)$ value. Similarly, catalase and peroxidase enzyme activities were enhanced during extreme drought (300-400 mM mannitol) and salinity (150-200 mM NaCl) conditions, compared to untransformed control. Wild type control plant leaves were completely necrotized by Aspergillus fumigatus (FCBP 66) and Fusarium solani (FCBP 0291), whereas transformed leaves had improved antifungal resistance. In conclusion, our data suggest that rolABC genes have a significant impact on the synthesis of metabolites involved in enhancing multistress tolerance in A. bracteosa.
\end{abstract}

Key words: Ajuga bracteosa, rolABC, real-time quantitative PCR, GC-MS, principal component analysis, biotic and abiotic stress

\section{Introduction}

Plants are prone to a wide variety of environmental stresses due to their sessile and restricted nature. Overproduction of reactive oxygen species (ROS) under stress conditions can cause plant cell death. To deter this, plants use antioxidant systems which include different enzymes and primary and secondary metabolites (Czarnocka and Karpinski, 2018).

Plants accumulate a repertoire of defense-related metabolites in specialized compartments e.g., trichomes. Several lines of evidence suggest that trichome development is regulated by transparent testa glabra1 (TTG1) gene regulatory network (Airoldi et al., 2019). Plant metabolites are synthesized through mevalonate (MVA), 2-c-methyl-d-erythritol-4-phosphate (MEP), shikimate, or combined pathways (Isah et al., 2018). The different rate-limiting steps of these pathways are regulated by HMG-CoA reductase (HMGR), 1-hydroxy-2-methyl2-(E)-butenyl-4-diphosphate synthase (HDS), farnesyl diphosphate synthase (FDS), and phenyl ammonia lyase $(P A L)$ (Dudareva et al., 2013), as described in Figure 1.

\footnotetext{
*Correspondence: bushramirza@qau.edu.pk
}

Traditionally, a considerable number of medicinal plants have been used as natural sources of antioxidants. Ajuga bracteosa Wall. ex Benth. (Lamiaceae) is an important medicinal plant that is broadly distributed in the Himalayan range (Park et al., 2017). A large number of pharmaceutically important compounds have been identified and characterized in this plant. Unfortunately, the yield of these phytochemicals in the wild plant is very low and is further compromised by environmental stress and lack of proper cultivation practices (Ahmad et al., 2012). Recent advances in genetic engineering offer a promising approach for instigating the production of secondary metabolites in hairy roots. However, tissue or organ specificity for the synthesis and translocation of certain groups of metabolites hinders the development of hairy root cultures (Isah, 2019).

To solve this problem, Kayani et al. (2016a) regenerated A. bracteosa plants from transgenic hairy roots and found improved production of phytoecdysteroids in regenerants. However, the molecular basis for the increase was not known. 


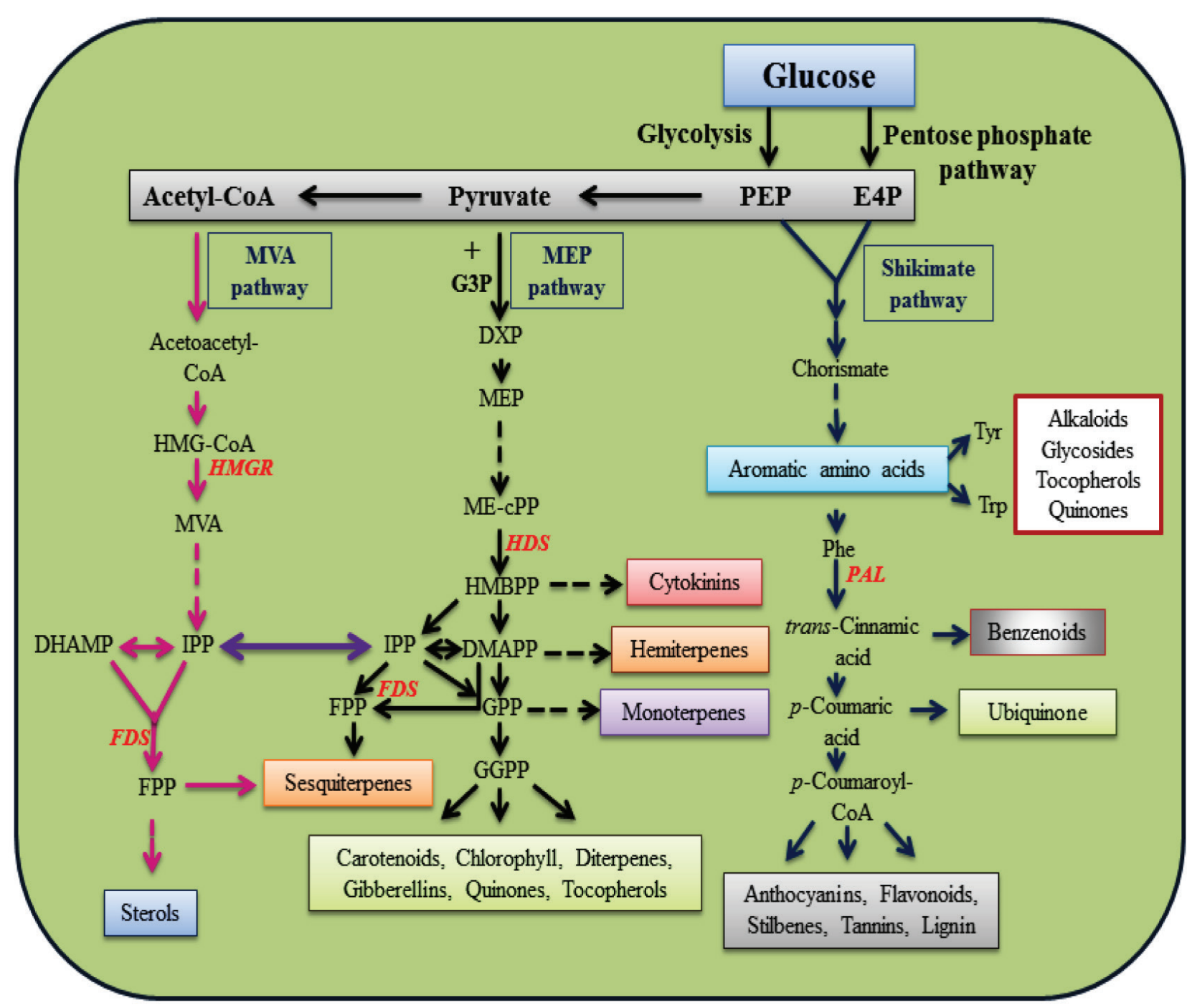

Figure 1. Overview of biosynthetic pathways for certain classes of plant secondary metabolites from glucose. E4P = Erythrose 4-phosphate, PEP = Phosphoenolpyruvate, HMG-CoA $=\beta$-Hydroxy $\beta$-methylglutaryl-CoA, HMGR $=\beta$-Hydroxy $\beta$-methylglutarylCoA reductase, $\mathrm{MVA}=$ Mevalonate, $\mathrm{IPP}=$ Isopentenyl pyrophosphate, $\mathrm{DHAMP}=$ Dimethylallyl diphosphate, FDS $=$ Farnesyl diphosphate synthase, FPP = Farnesyl diphosphate, G3P = Glyceraldehyde 3-phosphate, DXP = 1-deoxy-d-xylulose 5-phosphate, MEP $=2$ - $c$-methylerythritol 4-phosphate, ME-cPP = 2-c-methyl-d-erythritol 2,4-cyclodiphosphate, HMBPP = (E)-4-Hydroxy-3-methylbut-2-enyl pyrophosphate, HDS = (E)-4-Hydroxy-3-methyl-but-2-enyl pyrophosphate synthase, DMAPP = Dimethylallyl diphosphate, GPP $=$ Geranyl diphosphate, GGPP = Geranylgeranyl diphosphate, Tyr $=$ Tyrosine, Trp $=$ Tryptophan, Phe $=$ Phenylalanine, PAL $=$ Phenylalanine ammonia lyase. Genes assayed in this study are represented in red.

Moreover, the correlation of rol genes to cope with stresses has not been observed in medicinal plants. Here, we explored these issues by using the intact regenerated plants from the transgenic hairy root lines of $A$. bracteosa and suggest a possible impact of rolABC on the expression of some of the genes involved in the biosynthetic pathways of therapeutically important secondary metabolites. In addition, we tried to explain the possible involvement of the rol genes in coping with stress through up- and downregulation of the genes involved in secondary metabolism.

\section{Materials and methods}

\subsection{Source of plant material}

The plant material was collected from the grounds of Quaid-i-Azam University, İslamabad, Pakistan. These plants were identified by Prof. Dr. Rizwana Aleem Qureshi (taxonomist), Department of Plant Sciences, Quaid-iAzam University. A voucher specimen (no. HPM-460) was deposited in the herbarium of Quaid-i-Azam University. These fresh field plants (Figure 2a) were surface sterilized with bleach (sodium hypochlorite, 30\% v/v) for $15 \mathrm{~min}$, rinsed in ethanol $(70 \% \mathrm{v} / \mathrm{v})$ for $1 \mathrm{~min}$, and then washed 
with sterile deionized water ( 3 times) by swirling the plant parts. Finally, the plant parts were dried on sterile blotting papers, and nodal region explants were carefully retrieved and tissue cultured (Figure 2b) on MS medium (Murashige and Skoog, 1962) containing the best hormonal combinations for tissue culture, as optimized by our group (MS supplemented with $2 \mu \mathrm{M}$ BAP and solidified with $0.8 \%$ Phytagel) (Kayani et al., 2016b). The media of the tissue-cultured explants were changed every 10 days for 30 days and every second week thereafter.

\subsection{Transformation and regeneration}

In vitro grown plants 2-3-months old (Figure 2c) were used as explants for A. rhizogenes-mediated (LBA-9402 harboring $\mathrm{pRi}$ ) genetic transformation. The transformation procedure and growth media for hairy root induction, proliferation, and stabilization were previously optimized by Kayani et al. (2016a) and followed accordingly. The hairy root lines obtained after infection were maintained in the growth room at $27 \pm 2{ }^{\circ} \mathrm{C}$ in darkness (Figure $2 \mathrm{~d}$ ). We selected three transformed hairy root lines, numbered R02, R04, and R06, based on their growth rate and metabolite production rate. Intact plants (ABRL1, ABRL2, and ABRL3) were regenerated from these hairy root lines according to the already optimized protocol of Tanaka and Matsumoto (1993). For multiple shooting, medium was supplemented with $2 \mu \mathrm{M}$ BAP and plants were placed in the light while maintaining growth room conditions.
When regenerants reached an optimum size (Figure 2e), they were micropropagated on plain MS medium. After 3-4 months rooted shoots were acclimatized into pots containing peat moss and sand (Figure 2f).

\subsection{Confirmation of genetic integration}

\subsubsection{Polymerase chain reaction}

The presence of rolABC genes in putatively transformed and regenerated plants was confirmed by polymerase chain reaction (PCR). Already optimized conditions were used for genomic DNA isolation, plasmid DNA (positive control) extraction, and detection of rolA by PCR (Kiani et al., 2014). The sequences of the primers of rolA gene are given in Supplementary Table 1.

\subsubsection{Expression analysis}

\subsubsection{Total RNA extraction and cDNA synthesis}

The TRIzol/ice based method (Luz et al., 2016) was used to extract RNA from transformed and wild type plant leaves, with slight modification. Briefly, plant samples (200 mg each) were freeze-dried, finely crushed, and homogenized with $1 \mathrm{~mL}$ of TRIzol". Then, $400 \mu \mathrm{L}$ of chloroform was added to this homogenate and subjected to centrifugation at $12,000 \mathrm{rpm}$ for $10 \mathrm{~min}$ at $4{ }^{\circ} \mathrm{C}$. The supernatant was transferred to a new tube, placed on ice, and prechilled isopropanol was added in an equal ratio. Afterward, samples were centrifuged again under the abovementioned conditions. The pellet (containing RNA) was washed with
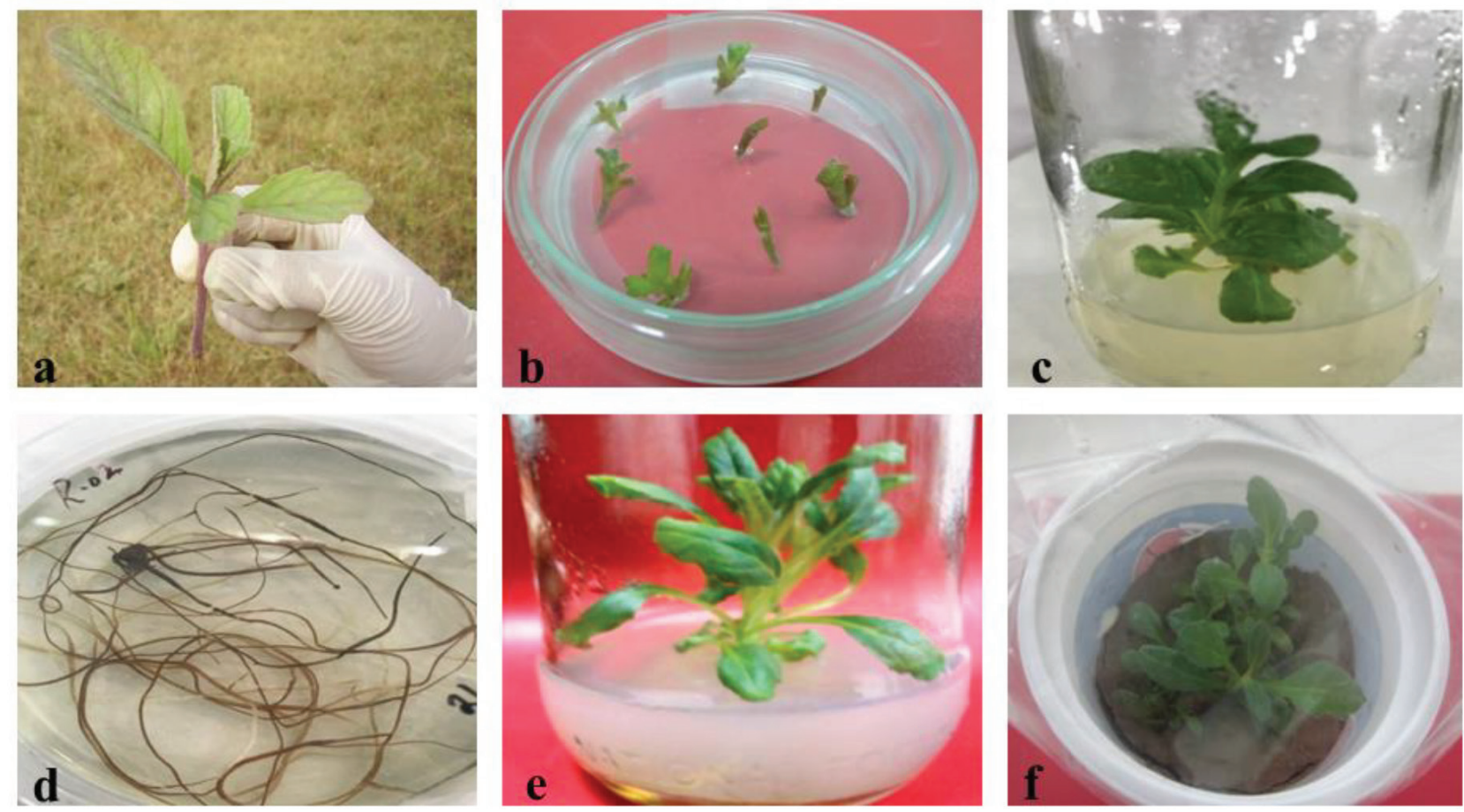

Figure 2. Development of intact regenerated plants from transgenic hairy roots. a: Plant collection from field. b: Surface sterilized nodal regions. c: In vitro grown tissue cultured plant. d: Transgenic hairy roots. e: Regenerated plant from hairy roots. f: Acclimatization in soil. 
Table 1. Phytocomponents identified in aerial parts of Ajuga bracteosa by GC-MS.

\begin{tabular}{|c|c|c|c|c|c|c|c|}
\hline \multirow{2}{*}{ RT } & \multirow{2}{*}{ Identified compounds } & \multicolumn{4}{|c|}{$\%$ Area in extracts } & \multirow{2}{*}{ Mol. formula } & \multirow{2}{*}{$\begin{array}{l}\text { Mol. } \\
\text { Wt. }\end{array}$} \\
\hline & & WT & ABRL1 & ABRL2 & ABRL3 & & \\
\hline & Terpenes and relatives & & & & & & \\
\hline 6.61 & 6,6-dimethyl-2,4-cyclohexadien-1-one & - & 1.21 & 0.89 & 1.60 & $\mathrm{C}_{8} \mathrm{H}_{10} \mathrm{O}$ & 122 \\
\hline 20.26 & Neophytadiene & - & 1.36 & 2.15 & 2.22 & $\mathrm{C}_{20} \mathrm{H}_{38}$ & 278 \\
\hline 8.75 & 1-methoxy-1,3-cyclohexadiene & - & 0.38 & 0.89 & 0.96 & $\mathrm{C}_{7} \mathrm{H}_{10} \mathrm{O}$ & 110 \\
\hline 23.38 & 1-Heneicosyl formate & - & 4.20 & 3.45 & 6.35 & $\mathrm{C}_{22} \mathrm{H}_{44} \mathrm{O}_{2}$ & 340 \\
\hline \multirow[t]{2}{*}{27.09} & Phytol & - & 0.59 & 0.58 & 0.65 & $\mathrm{C}_{20} \mathrm{H}_{40} \mathrm{O}$ & 128 \\
\hline & Esters and acids & & & & & & \\
\hline 4.88 & $\begin{array}{l}(2 S, 4 S, 6 S)-(6-B e n z e n e s u l f o n y l-4-m e t h o x y t e t r a h y d r o p y r a n-2-y l) \\
\text { acetic acid methyl ester }\end{array}$ & - & 1.48 & 2.00 & 2.08 & $\mathrm{C}_{15} \mathrm{H}_{20} \mathrm{O}_{6} \mathrm{~S}$ & 328 \\
\hline 17.52 & Sulfurous acid, 2-propyl tetradecyl ester & 1.20 & 0.92 & 0.88 & 0.80 & $\mathrm{C}_{17} \mathrm{H}_{36} \mathrm{O}_{3} \mathrm{~S}$ & 320 \\
\hline 17.53 & Oxalic acid, 2-ethylhexyl octyl ester & 1.2 & - & - & - & $\mathrm{C}_{18} \mathrm{H}_{34} \mathrm{O}_{4}$ & 314 \\
\hline 17.94 & 4,5-Dimethoxy-3-hydroxybenzoic acid methyl ester & - & 1.86 & 2.30 & 2.43 & $\mathrm{C}_{10} \mathrm{H}_{12} \mathrm{O}_{5}$ & 212 \\
\hline 21.04 & Sulfurous acid, hexyl octyl ester & 0.94 & 0.96 & 0.85 & 0.7 & $\mathrm{C}_{14} \mathrm{H}_{30} \mathrm{O}_{3} \mathrm{~S}$ & 278 \\
\hline 21.40 & 2,6-Undecadienoic acid, 7-ethyl-3-methyl-methyl-ester & - & 2.18 & - & - & $\mathrm{C}_{15} \mathrm{H}_{26} \mathrm{O}_{2}$ & 238 \\
\hline 22.01 & Hexadecanoic acid, methyl ester (CAS) & - & 0.56 & 0.77 & 0.92 & $\mathrm{C}_{17} \mathrm{H}_{34} \mathrm{O}_{2}$ & 270 \\
\hline 22.41 & Sulfurous acid, butyl tetradecyl ester & 0.53 & 0.29 & 0.40 & 0.40 & $\mathrm{C}_{17} \mathrm{H}_{36} \mathrm{O}_{3} \mathrm{~S}$ & 320 \\
\hline 22.64 & Octatriacontyl pentafluoropropionate & 0.51 & - & - & 0.43 & $\mathrm{C}_{41} \mathrm{H}_{77} \mathrm{~F}_{5} \mathrm{O}_{2}$ & 697 \\
\hline 22.78 & 1-(+)-Ascorbic acid 2,6-dihexadecanoate & - & 0.68 & 1.20 & 1.98 & $\mathrm{C}_{38} \mathrm{H}_{68} \mathrm{O}_{8}$ & 652 \\
\hline 23.03 & Heptadecyl heptafluorobutyrate & 0.41 & - & - & 0.25 & $\mathrm{C}_{21} \mathrm{H}_{35} \mathrm{~F}$ & 452 \\
\hline 23.18 & Phthalic acid, butyl tetradecyl ester & 0.42 & - & 0.26 & 0.28 & $\mathrm{C}_{26} \mathrm{H}_{42} \mathrm{O}_{4}$ & 418 \\
\hline 24.71 & Sulfurous acid, butyl dodecyl ester & 1.14 & 0.38 & 1.62 & 1.33 & $\mathrm{C}_{16} \mathrm{H}_{34} \mathrm{O}_{3} \mathrm{~S}$ & 306 \\
\hline 25.15 & 6-Tetradecanesulfonic acid, butyl ester & 0.59 & - & - & - & $\mathrm{C}_{18} \mathrm{H}_{38} \mathrm{O}_{3} \mathrm{~S}$ & 334 \\
\hline 25.31 & 9,12,15-Octadecatrienoic acid, methyl ester (CAS) & - & 1.66 & 1.65 & 1.70 & $\mathrm{C}_{19} \mathrm{H}_{32} \mathrm{O}_{2}$ & 292 \\
\hline 25.39 & Nonahexacontanoic acid & 1.19 & 1.27 & 1.22 & 0.96 & $\mathrm{C}_{69} \mathrm{H}_{138} \mathrm{O}_{2}$ & 999 \\
\hline 26.37 & 9-Octadecenoic acid (Z)- (CAS) & - & 0.79 & 0.83 & 1.01 & $\mathrm{C}_{18} \mathrm{H}_{34} \mathrm{O}_{2}$ & 282 \\
\hline 27.56 & 912 15-octadecatrienoic acid methyl ester & - & - & - & 2.81 & $\mathrm{C}_{19} \mathrm{H}_{32} \mathrm{O}_{2}$ & 292 \\
\hline 27.89 & Octadecanoic acid & - & 0.51 & - & 3.34 & $\mathrm{C}_{18} \mathrm{H}_{36} \mathrm{O}_{2}$ & 284 \\
\hline 29.66 & $\begin{array}{l}\text { Glycine,N-[(3à,5á)-24-oxo-3-[(trimethylsilyl)oxy]cholan-24-yl]- } \\
\text {,methyl ester (CAS) }\end{array}$ & - & 0.82 & 0.63 & 1.05 & $\mathrm{C}_{30} \mathrm{H}_{53} \mathrm{NO}_{4} \mathrm{Si}$ & 519 \\
\hline 30.55 & Methoxyacetic acid, 3-tetradecyl & - & 2.05 & - & - & $\mathrm{C}_{17} \mathrm{H}_{34} \mathrm{O}_{3}$ & 286 \\
\hline \multirow[t]{2}{*}{33.22} & Bis(2-ethylhexyl) phthalate & 5.49 & 6.34 & 7.13 & 8.49 & $\mathrm{C}_{24} \mathrm{H}_{38} \mathrm{O}_{4}$ & 390 \\
\hline & Ether & & & & & & \\
\hline \multirow[t]{2}{*}{23.67} & Tetradecyl ether & - & - & - & 0.37 & $\mathrm{C}_{28} \mathrm{H}_{58} \mathrm{O}$ & 410 \\
\hline & Compounds with benzene ring & & & & & & \\
\hline 13.21 & 2-Allyl-5-t-butylhydroquinone & - & 5.44 & 6.99 & 8.70 & $\mathrm{C}_{13} \mathrm{H}_{18} \mathrm{O}_{2}$ & 206 \\
\hline 16.55 & phenol 2 4-bis(1 1-dimethylethyl) & 4.01 & 4.79 & 4.40 & 5.19 & $\mathrm{C}_{14} \mathrm{H}_{22} \mathrm{O}$ & 206 \\
\hline 16.90 & $\begin{array}{l}\text { 7-Hydroxy-2-methyl-2,3-dihydro-1H-cyclopenta[a]naphthalen-1- } \\
\text { one }\end{array}$ & - & 0.32 & 0.77 & 0.91 & $\mathrm{C}_{14} \mathrm{H}_{12} \mathrm{O}_{2}$ & 212 \\
\hline 38.32 & 4-Butyl-1,3,8-trihydroxy-6-methoxyanthraquinone & - & 0.59 & 0.53 & 1.16 & $\mathrm{C}_{19} \mathrm{H}_{18} \mathrm{O}_{6}$ & 342 \\
\hline 39.43 & 5,8-Dimethoxy-4-(2-nitrophenyl)-2(1H)-quinolinone & - & 4.80 & 5.69 & 7.53 & $\mathrm{C}_{17} \mathrm{H}_{14} \mathrm{~N}_{2} \mathrm{O}_{5}$ & 326 \\
\hline
\end{tabular}


Table 1. (Continued).

\begin{tabular}{|c|c|c|c|c|c|c|c|}
\hline & $\mathrm{N}, \mathrm{S}, \mathrm{Si}$, furan compounds & & & & & & \\
\hline 16.76 & Tricosyl trifluoroacetate & 1.27 & 1.02 & - & - & $\mathrm{C}_{25} \mathrm{H}_{47} \mathrm{~F}_{3} \mathrm{O}_{2}$ & 436 \\
\hline 19.87 & 9,9-Dimethyl-9-silafluorene & 0.64 & 0.50 & 0.49 & 0.36 & $\mathrm{C}_{14} \mathrm{H}_{14} \mathrm{Si}$ & 210 \\
\hline 20.88 & Octacosyl trifluoroacetate & - & 1.03 & 1.00 & 0.75 & $\mathrm{C}_{30} \mathrm{H}_{57} \mathrm{~F}_{3} \mathrm{O}_{2}$ & 506 \\
\hline 26.98 & Octadecanenitrile & 0.62 & 0.86 & 0.92 & 0.66 & $\mathrm{C}_{18} \mathrm{H}_{35} \mathrm{~N}$ & 265 \\
\hline \multirow[t]{2}{*}{35.79} & 13-Docosenamide, (Z)- & - & 9.43 & 8.69 & 15.04 & $\mathrm{C}_{22} \mathrm{H}_{43} \mathrm{NO}$ & 337 \\
\hline & Alcohols, aldehydes, ketones & & & & & & \\
\hline 7.00 & Ethanone, 1-cyclopentyl- & 0.65 & 0.55 & 0.78 & 0.57 & $\mathrm{C}_{7} \mathrm{H}_{12} \mathrm{O}$ & 112 \\
\hline 9.26 & 1-(2-Ethyl-1,3-dimethyl-cyclopent-2-enyl)-ethanone & - & 0.98 & 0.83 & 1.02 & $\mathrm{C}_{11} \mathrm{H}_{18} \mathrm{O}$ & 166 \\
\hline 10.93 & 1-Hexadecanol (CAS) & - & 3.12 & 4.30 & 5.78 & $\mathrm{C}_{16} \mathrm{H}_{34} \mathrm{O}$ & 242 \\
\hline 25.65 & Octadecanal & 1.92 & 2.99 & 2.93 & 2.81 & $\mathrm{C}_{18} \mathrm{H}_{36} \mathrm{O}$ & 268 \\
\hline 27.21 & 1-Heneicosanol & - & 3.60 & 4.18 & 4.21 & $\mathrm{C}_{21} \mathrm{H}_{44} \mathrm{O}$ & 312 \\
\hline \multirow[t]{2}{*}{30.08} & n-Tetracosanol-1 & - & 2.52 & 2.31 & 2.53 & $\mathrm{C}_{24} \mathrm{H}_{50} \mathrm{O}$ & 354 \\
\hline & Hydrocarbons & & & & & & \\
\hline 5.39 & Dodecane, 4,6-dimethyl- & 0.32 & 0.30 & 0.25 & 0.21 & $\mathrm{C}_{14} \mathrm{H}_{30}$ & 198 \\
\hline 6.90 & 2-Undecene, 4-methyl- & 0.73 & 0.55 & 0.54 & 0.49 & $\mathrm{C}_{12} \mathrm{H}_{24}$ & 168 \\
\hline 11.51 & Heptadecane, 8-methyl- & 0.47 & 0.37 & 0.78 & 0.57 & $\mathrm{C}_{18} \mathrm{H}_{38}$ & 254 \\
\hline 12.10 & Cyclohexane, 1,3,5-trimethyl- & 1.97 & 1.49 & 1.46 & 1.23 & $\mathrm{C}_{9} \mathrm{H}_{18}$ & 126 \\
\hline 12.30 & Cyclohexane, 1,2,4-trimethyl- & 2.35 & 1.78 & 1.74 & 1.45 & $\mathrm{C}_{9} \mathrm{H}_{18}$ & 126 \\
\hline 12.48 & Cyclohexane, 1,2-diethyl-1-methyl- & 1.47 & 1.14 & 1.14 & 0.97 & $\mathrm{C}_{11} \mathrm{H}_{22}$ & 154 \\
\hline 12.54 & Dodecane & 1.09 & 0.77 & 0.71 & 0.33 & $\mathrm{C}_{12} \mathrm{H}_{26}$ & 170 \\
\hline 12.78 & Tetradecane, 4-methyl- & 0.53 & 0.39 & - & - & $\mathrm{C}_{15} \mathrm{H}_{32}$ & 212 \\
\hline 12.91 & Hexane, 3,3-dimethyl- & 0.37 & 0.29 & 0.89 & 0.58 & $\mathrm{C}_{8} \mathrm{H}_{18}$ & 114 \\
\hline 15.49 & Dodecane, 4,6-dimethyl- & 0.63 & 0.48 & 0.49 & 0.39 & $\mathrm{C}_{13} \mathrm{H}_{28}$ & 184 \\
\hline 15.66 & Hexadecane, 7-methyl- & 0.91 & 0.47 & 0.73 & 0.58 & $\mathrm{C}_{17} \mathrm{H}_{36}$ & 240 \\
\hline 15.87 & Decane, 2,3,8-trimethyl- & 0.97 & 0.95 & 0.89 & 0.58 & $\mathrm{C}_{13} \mathrm{H}_{28}$ & 184 \\
\hline 16.07 & Decane, 2,3,5,8-tetramethyl- & 0.41 & 0.33 & 0.31 & 0.28 & $\mathrm{C}_{14} \mathrm{H}_{30}$ & 198 \\
\hline 16.19 & Octacosane & 0.80 & 0.78 & 0.76 & 1.86 & $\mathrm{C}_{28} \mathrm{H}_{58}$ & 394 \\
\hline 16.25 & Pentadecane & 0.34 & 0.96 & 2.15 & 0.81 & $\mathrm{C}_{15} \mathrm{H}_{32}$ & 212 \\
\hline 17.09 & 10-Methylnonadecane & 0.32 & 2.21 & - & 1.86 & $\mathrm{C}_{20} \mathrm{H}_{42}$ & 282 \\
\hline 17.47 & Tetratetracontane & 0.52 & 0.60 & 0.90 & 0.45 & $\mathrm{C}_{44} \mathrm{H}_{90}$ & 619 \\
\hline 17.68 & Tetracosane & 0.46 & 0.65 & 0.45 & 1.31 & $\mathrm{C}_{24} \mathrm{H}_{50}$ & 338 \\
\hline 18.24 & Hexadecane & 1.19 & 0.70 & 0.67 & 0.65 & $\mathrm{C}_{16} \mathrm{H}_{34}$ & 226 \\
\hline 19.19 & Hexadecane, 7,9-dimethyl- & 0.32 & 0.78 & 0.73 & 0.39 & $\mathrm{C}_{18} \mathrm{H}_{38}$ & 254 \\
\hline 19.36 & 1-Octadecene (CAS) & - & 5.66 & 6.09 & 6.57 & $\mathrm{C}_{18} \mathrm{H}_{36}$ & 252 \\
\hline 20.01 & 3-Heptadecene, (Z)- & 0.63 & - & - & - & $\mathrm{C}_{17} \mathrm{H}_{34}$ & 238 \\
\hline 20.14 & Heptadecane & 1.59 & 1.80 & 0.80 & 0.66 & $\mathrm{C}_{17} \mathrm{H}_{36}$ & 240 \\
\hline 20.25 & Pentadecane, 2,6,10,14 tetramethyl- & 1.03 & 0.48 & 0.35 & 0.48 & $\mathrm{C}_{19} \mathrm{H}_{40}$ & 268 \\
\hline 20.50 & Pentadecane & 0.52 & 0.60 & 0.60 & 0.81 & $\mathrm{C}_{15} \mathrm{H}_{32}$ & 212 \\
\hline 20.88 & Cyclohexane, 1,2,4-trimethyl- & 1.12 & 1.03 & 1.00 & 1.73 & $\mathrm{C}_{9} \mathrm{H}_{18}$ & 126 \\
\hline 21.14 & 3,5-Dimethyldodecane & 2.13 & 2.42 & 2.28 & 1.83 & $\mathrm{C}_{14} \mathrm{H}_{30}$ & 198 \\
\hline 21.30 & Octadecane & 0.96 & 1.14 & 1.11 & 3.06 & $\mathrm{C}_{18} \mathrm{H}_{38}$ & 254 \\
\hline 21.47 & Pentacosane & 0.60 & \begin{tabular}{|l|}
0.98 \\
\end{tabular} & 0.88 & \begin{tabular}{|l}
0.99 \\
\end{tabular} & $\mathrm{C}_{25} \mathrm{H}_{52}$ & 352 \\
\hline
\end{tabular}


Table 1. (Continued).

\begin{tabular}{|l|l|l|l|l|l|l|l|}
\hline 21.56 & Pentadecane, 2,6,10-trimethyl- & 1.48 & 1.85 & 1.85 & 1.33 & $\mathrm{C}_{18} \mathrm{H}_{38}$ & 254 \\
\hline 21.78 & Eicosane & 1.51 & 3.73 & 1.22 & 0.78 & $\mathrm{C}_{20} \mathrm{H}_{42}$ & 282 \\
\hline 21.94 & Hexacosane & 1.30 & 0.84 & 0.88 & 1.57 & $\mathrm{C}_{26} \mathrm{H}_{54}$ & 366 \\
\hline 21.99 & 3-Hexene, 2,2,5,5-tetramethyl- & 1.11 & 0.86 & 0.90 & 0.64 & $\mathrm{C}_{10} \mathrm{H}_{20}$ & 140 \\
\hline 22.12 & Hexadecane, 2,6,10,14-tetramethyl- & 1.23 & 0.75 & 0.84 & 0.48 & $\mathrm{C}_{20} \mathrm{H}_{42}$ & 282 \\
\hline 22.25 & Oxirane, hexadecyl- & 1.00 & 1.35 & - & - & $\mathrm{C}_{18} \mathrm{H}_{36} \mathrm{O}$ & 268 \\
\hline 22.32 & Heptadecane, 9-octyl- & 0.37 & 0.37 & 0.38 & 0.30 & $\mathrm{C}_{25} \mathrm{H}_{52}$ & 352 \\
\hline 23.66 & Nonadecane & 0.43 & 0.52 & 0.52 & 0.37 & $\mathrm{C}_{19} \mathrm{H}_{40}$ & 268 \\
\hline 23.76 & Octadecane, 2-methyl- & 0.44 & - & - & 0.31 & $\mathrm{C}_{19} \mathrm{H}_{40}$ & 268 \\
\hline 24.78 & Heptacosane & 2.89 & 4.40 & 5.59 & 10.82 & $\mathrm{C}_{27} \mathrm{H}_{56}$ & 380 \\
\hline 24.83 & Tetrapentacontane & 0.52 & 0.66 & 0.59 & 1.86 & $\mathrm{C}_{54} \mathrm{H}_{110}$ & 759 \\
\hline 24.91 & Hentriacontane & 0.56 & 0.60 & 0.59 & 1.44 & $\mathrm{C}_{31} \mathrm{H}_{64}$ & 436 \\
\hline 25.29 & Triacontane & 1.02 & 1.19 & 1.06 & 0.75 & $\mathrm{C}_{30} \mathrm{H}_{62}$ & 422 \\
\hline 26.06 & Eicosane, 2-methyl- & 0.36 & 0.72 & 1.40 & 0.69 & $\mathrm{C}_{21} \mathrm{H}_{44}$ & 296 \\
\hline 26.63 & Cyclotetradecane & - & 0.46 & - & - & $\mathrm{C}_{14} \mathrm{H}_{28}$ & 196 \\
\hline 26.87 & Heneicosane & 0.62 & 2.57 & 2.61 & 3.06 & $\mathrm{C}_{21} \mathrm{H}_{44}$ & 296 \\
\hline 28.52 & Decane, 3,6-dimethyl- & 0.58 & 0.59 & 0.53 & 1.34 & $\mathrm{C}_{12} \mathrm{H}_{26}$ & 170 \\
\hline 28.73 & Tridecane, 2-methyl- & 0.63 & - & - & 1.19 & $\mathrm{C}_{14} \mathrm{H}_{30}$ & 198 \\
\hline 29.01 & 2-methylhexacosane & 1.30 & 1.21 & 1.13 & 0.91 & $\mathrm{C}_{27} \mathrm{H}_{56}$ & 380 \\
\hline 29.14 & Pentadecane, 3-methyl- & 0.46 & 0.49 & 0.36 & - & $\mathrm{C}_{16} \mathrm{H}_{34}$ & 226 \\
\hline 29.37 & Dotriacontane & 0.35 & 0.59 & - & - & $\mathrm{C}_{32} \mathrm{H}_{66}$ & 450 \\
\hline 30.99 & Heneicosane, 11-(1-ethylpropyl)- & 0.58 & 2.57 & - & 2.14 & $\mathrm{C}_{26} \mathrm{H}_{54}$ & 366 \\
\hline 31.12 & Docosane & 1.53 & - & 1.04 & 1.57 & $\mathrm{C}_{22} \mathrm{H}_{46}$ & 310 \\
\hline 32.63 & 9-Hexacosene & - & 1.45 & 1.59 & 1.68 & $\mathrm{C}_{26} \mathrm{H}_{52}$ & 364 \\
\hline
\end{tabular}

$\mathrm{WT}=$ Tissue cultured untransformed line, $\mathrm{ABRL1}, 2,3=$ A. bracteos $a$ transformed regenerants line 1, 2 and 3, RT=Retention time, Mol. Wt. = Molecular weight.

ethanol (70\% v/v) 3 times and air-dried completely. Then $40 \mu \mathrm{L}$ of diethyl pyrocarbonate (DEPC) was added. The purity of total RNA was assessed by Nanodrop (Skanit RE 4.1, Thermo Fisher Scientific Inc., Waltham, MA, USA). Then, cDNA was synthesized by reverse transcription of $1 \mu \mathrm{g}$ of RNA using Viva cDNA synthesis kit (Vivantis cDSK01-050), following manufacturer's instructions, and stored at $-20^{\circ} \mathrm{C}$ for downstream analysis.

\subsubsection{Real-time quantitative PCR}

To evaluate the possible effects of rol genes on the phytochemical biosynthesis in MEP, MVA, and shikimate pathways, quantitative real-time PCR (qPCR) of 5 selected genes was performed. PCR conditions were optimized for genes encoding HMGR, HDS, FDS, PAL, and TTG1, accordingly. The amplification reaction was accomplished by gene-specific primers, as shown in Supplementary Table 1. The qPCR was conducted using a Mic PCR machine (Bio Molecular Systems) with 1X Eva Green PCR master mix. For real-time qPCR, a 1:10 dilution of
cDNA was used. The reaction conditions for qPCR were as follows: an initial cycle of denaturation for $12 \mathrm{~min}$ at $95^{\circ} \mathrm{C}$, followed by 40 cycles each of denaturation for $15 \mathrm{~s}$ at $95{ }^{\circ} \mathrm{C}$, primer annealing for $20 \mathrm{~s}$ at $62^{\circ} \mathrm{C}$ (for all genes), and elongation for $20 \mathrm{~s}$ at $72{ }^{\circ} \mathrm{C}$. Two biological samples were analyzed, while three technical replicates were used for each biological sample; the melting curve of amplicons confirmed the absence of primer dimers at the end of each run. The relative gene expression levels were normalized with the endogenous reference gene $(\beta$-actin).

\subsection{Phytochemical screening}

\subsubsection{Sample preparation}

Dried aerial parts (5 $\mathrm{g}$ each) of $A$. bracteosa were crushed into a fine powder and extracted with methanol/ chloroform (solvent-to-powder, 5:1, v/w) for $72 \mathrm{~h}$ at room temperature. The supernatant was filtered, and the process was repeated three times. The resulting extracts were combined, air-dried, and concentrated under vacuum. 


\subsubsection{Gas chromatography and mass spectrometry (GC- MS)}

Gas chromatography and mass spectrometry analysis was carried out with Thermo GC-TRACE ultra (v. 5.0) Thermo MS DSQ II (Thermo Fischer Scientific Inc.) fitted with a DB5-MS nonpolar capillary column (30 m length, $0.25 \mathrm{~mm}$ id, and $0.25 \mu \mathrm{m}$ film thickness). Crude plant samples were completely dissolved in n-hexane and analyzed with GCMS under the following experimental conditions: mobile phase (helium used as a carrier gas) with a flow rate of 1 $\mathrm{mL} / \mathrm{min}$ and $1 \mu \mathrm{L}$ injection volume. GC oven temperature was initially held at $70{ }^{\circ} \mathrm{C}$ and raised to $260^{\circ} \mathrm{C}$ at $6{ }^{\circ} \mathrm{C} / \mathrm{min}$, and samples were fully run at 50-650 m/z. Identification of constituent compounds in crude samples was based on comparing their retention times and mass spectra with the known mass spectra stored in the National Institute of Standards and Technology (NIST) database search library. Principal component analysis (PCA) was carried out with the help of PAST 3.26 statistical software. The results of PCA are presented in terms of loading and scatter plots.

\subsection{Abiotic stress and its effect on photosynthetic} parameters

To assess the effect of stress on A. bracteosa regenerants, fresh green leaves from 3 independent transgenic lines (ABRL1, 2, and 3) and untransformed, in vitro grown wild type plants (WT) were propagated on MS media supplemented with $0,100,200,300$, and $400 \mathrm{mM}$ mannitol (for drought stress) and 0,50,100,150, and $200 \mathrm{mM} \mathrm{NaCl}$ (for salinity stress). For each treatment, leaves from WT and ABRL1, 2, and 3 were germinated in a growth room (21 days; $16 / 8 \mathrm{~h}$ photoperiod, $45 \mu \mathrm{E} \mathrm{m}^{2} \mathrm{~s}^{1}$ or 1000 lux light intensity, and $60 \%$ relative humidity). Each treatment was triplicated, and data were taken on the last day of the stress experiment.

The ratio of variable-to-maximum fluorescence $\left(F_{v} / F_{\mathrm{m}}\right)$ for the quantum efficiency of photosystem II (PSII) and the performance index $\left(\mathrm{PI}_{\text {abs }}\right.$ ) from drought- and salt-stressed leaves were measured by chlorophyll fluorometer (pocket PEA-v04; Adsotech Instruments Ltd., Kings Lynn, UK). The fluorescence of fully extended leaves was measured after 30 min for dark adaptation at full intensity $\left(3500 \mu \mathrm{m} \mathrm{m}^{-2} \mathrm{~s}^{-1}\right)$. Total chlorophyll content was determined by SPAD 502 chlorophyll meter as $\mu$ moles $/ \mathrm{m}^{2}$ of leaf (Netto et al., 2005).

\subsection{Estimation of relative water content}

Relative water content (RWC) of leaves under drought stress was calculated by taking the initial weight after stress application as fresh weight (FW). Then, all of the tested leaves were soaked in distilled water for $12 \mathrm{~h}$ to find their turgid weight (TW). Finally, dry weight (DW) was recorded after drying turgid leaves at $80^{\circ} \mathrm{C}$ for $24 \mathrm{~h}$ (Arndt et al., 2015). The following equation was used to calculate the RWC.

$$
\mathrm{RWC}(\%)=[(\mathrm{FW}-\mathrm{DW}) /(\mathrm{TW}-\mathrm{DW})] \times 100
$$

\subsection{Enzyme extract preparation}

Enzyme extracts of fresh leaves were prepared by following a previously reported method (Nayyar and Gupta, 2006) with some modifications. Briefly, $0.5 \mathrm{~g}$ of each leaf was freeze-dried and homogenized with $8 \mathrm{~mL}$ of enzyme extract solution containing $50 \mathrm{mM}$ potassium phosphate buffer ( $\mathrm{pH} 7.0)$ and $1 \%$ polyvinylpyrrolidone. The homogenate was centrifuged at $14,000 \mathrm{rpm}$ for 30 min, and the supernatant was collected and stored at $4{ }^{\circ} \mathrm{C}$ for further enzyme assays.

\subsection{Antioxidant enzyme assays}

Catalase (EC 1.11.1.6) enzyme activity was determined following Aebi's (1984) method, with slight modifications. The enzyme mixture $(3 \mathrm{~mL}$ ) consisted of $0.1 \mathrm{~mL}$ of enzyme

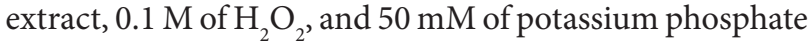
buffer ( $\mathrm{pH} 7.0$ ). The decline in optical activity at $240 \mathrm{~nm}$ was measured as catalase activity/g FW.

Peroxidase (EC 1.11.1.7) enzyme activity was determined using the guaiacol oxidation method by Chance and Machly (1955). The assay mixture $(0.2 \mathrm{~mL})$ contained $50 \mu \mathrm{L}$ of enzyme extract, $50 \mathrm{mM}$ of potassium phosphate buffer ( $\mathrm{pH} 7.0), 50 \mathrm{mM}$ of guaiacol, and $2 \%$ $\mathrm{H}_{2} \mathrm{O}_{2}$. Change in absorbance in $3 \mathrm{~min}$ at $470 \mathrm{~nm}$ due to the formation of tetraguaiacol was measured as peroxidase activity/g FW.

\subsection{Fungal resistance assays}

Fungal pathogens Aspergillus fumigatus (FCBP 66) and Fusarium solani (FCBP 0291) were propagated in Sabouraud dextrose agar medium. Fresh, green intact leaves were detached from $A$. bracteosa regenerated transgenic plants as well as wild plants, placed on the fungal cultures, and maintained at $28{ }^{\circ} \mathrm{C}$ and $16 / 8 \mathrm{~h}$ photoperiod for 6 days. Each petri plate contained two to three leaves with 5 replicates. Percentage of infection was measured using the following formula:

Percentage of infection $=$

(number of leaves infected-total number of leaves inoculated) $\times 100$

The same assay was repeated with an additional modification, i.e. petri plates were provided with already moist filter paper (to maintain humidity). A $5 \mathrm{~mm}$ filter paper disc containing microsclerotia of A. fumigatus and F. solani was placed in the central area of the leaf. The experiment was conducted at $28{ }^{\circ} \mathrm{C}$ and $16 / 8 \mathrm{~h}$ photoperiod. The leaf area necrotized by fungal infection was measured at 24,48 , and $72 \mathrm{~h}$ postinfection (hpi) (Chowdhury et al., 2017).

\subsection{Statistical analysis}

All experiments were performed in triplicate, and values were represented as mean $(n=3) \pm S D$. PAST 3.26 statistical software was used for PCA of phytochemicals detected via GC-MS. For qPCR analysis two biological 
and three technical replicates were used for each sample. The significance of difference was calculated between wild type control and transgenic plants by two-way analysis of variance (ANOVA) using GraphPad Prism 5. Statistical significance was indicated by $\mathrm{P} \leq 0.05$.

\section{Results and discussion}

3.1. Phenotype and molecular analysis of the transgenic plants

Nonchimeric A. bracteosa plants were regenerated from transgenic hairy roots in this study. These plants (harboring TL-DNA of pRi) presented morphological variability that was distinct from wild type A. bracteosa. The phenotype of regenerated plants was consistent with the previously reported data characteristic of $A$. bracteosa derived from transgenic hairy roots (Kayani et al., 2016a), i.e. they had a large number of curled leaves and short internodes with a bushy appearance. Plants regenerated from the transgenic hairy root lines were very different from the ones obtained from direct infection of $A$. tumefaciens harboring rolABC genes (Kayani et al., 2016b). Plants raised directly after the T-DNA transfer into tissue could be chimeric and had broad brittle leaves with ridges and furrows; the regenerants obtained from the hairy root lines were curled (like a bow) and not broad at all. PCR performed with rolA primers showed the presence of a $308 \mathrm{bp}$ amplicon in regenerated plantlets and plasmid DNA (Figure 3a). This product size was similar to previous reports for rolA gene (Kiani et al., 2014).

\subsection{Relative gene expression by quantitative real-time PCR}

Among all the studied rol genes, $r o l B$ is considered the most powerful inducer of secondary metabolites, but it hampers the growth of the plant and its phenotype. However, when rolB gene is coupled with other rol genes such as rolA and rolC, the detrimental effect of rolB is overcome (Bulgakov, 2008). To assess the up- and downregulation of biosynthetic pathways, we analyzed the expression of HMGR, HDS, FDS, PAL, and TTG1 genes in wild type and transgenic regenerants of $A$. bracteosa by quantitative real-time PCR. We found upregulation of the studied genes involved in biosynthesis of secondary metabolites under the effect of rol genes, as compared to the wild type (Figure $3 \mathrm{~b}$ ). Overall, these results implied that transgenic line ABRL3 had the highest expression of all genes studied. Data indicated that the expression of $P A L$ was highest, whereas HDS had the lowest expression among all genes.

Our findings are supported by previous reports which demonstrated that rolB and $C$ genes increased the amount of artemisinin and its derivatives in Artemisia annua by overexpressing the amorphadiene synthase (ADS), aldehyde dehydrogenase 1 (ALDH1), cytochrome P450, (CYP71AV1), PAL, cholane synthase (CHS), and trichomespecific fatty acyl-CoA reductase 1(TAFR1) genes (Dilshad et al., 2015, 2016). Furthermore, Kayani et al. (2016a, 2017) found that rolABC-positive hairy root clones of $A$. bracteosa produce enhanced phytoecdysteroid content (up to $4449 \mu \mathrm{g} \mathrm{g}^{-1}$ ) compared to control hairy roots. a

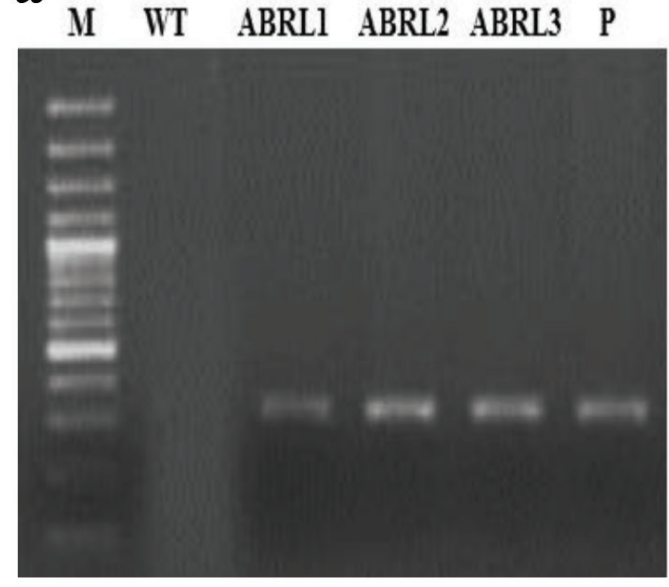

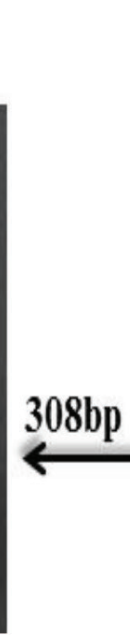

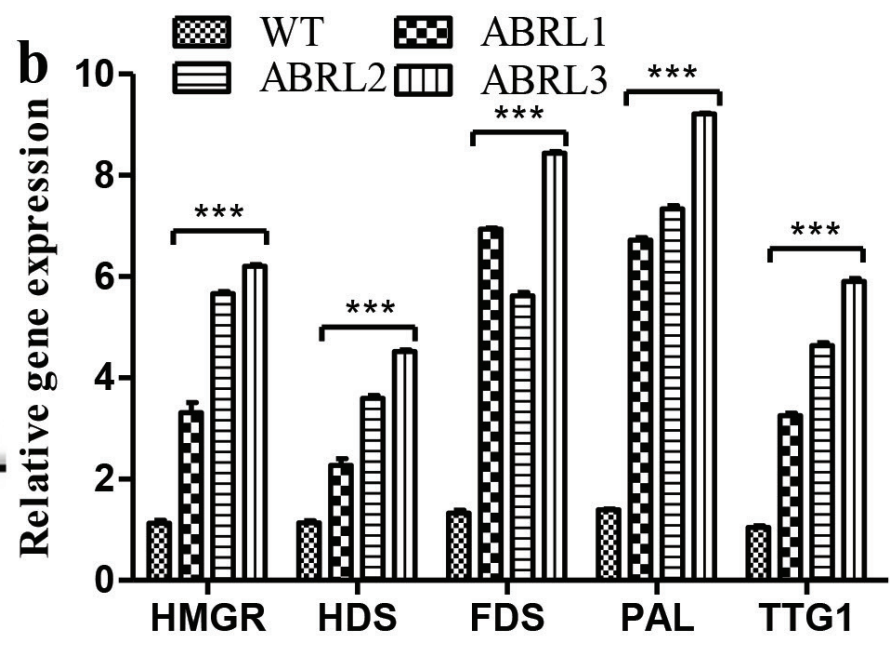

Figure 3. Confirmation of genetic integration in Ajuga bracteosa plants. a: Molecular analysis of A. bracteosa transgenic regenerants by conventional PCR. PCR amplification with rolA specific primers. Lane $M$ represents 100 bp DNA marker (Fermentas); WT stands for wild type tissue cultured plants; $A B R L 1-3$ are transgenic lines of A. bracteosa. P corresponds to plasmid DNA. b: Quantitative realtime PCR analysis of expression of genes encoding HMG-CoA reductase (HMGR); 1-hydroxy-2-methyl-2-(E)-butenyl-4-diphosphate synthase (HDS); farnesyl diphosphate synthase (FDS); phenyl ammonia lyase (PAL); transparent testa glabra1 (TTG1) in wild type and transgenic lines of $A$. bracteosa. The expression level was normalized with the $\beta$-actin reference gene. Data are expressed as mean \pm S.D. $\left({ }^{* * *} \mathrm{P}<0.001\right)$. 
Similarly, rolB and rolC genes of $A$. rhizogenes increased resveratrol content in Vitis amurensis through enhanced expression of PAL gene (Dubrovina et al., 2010). Another group found that rolB significantly enhanced the expression of MYB and TTG1 in Arabidopsis thaliana (Bulgakov et al., 2016).

\subsection{GC-MS analysis}

A large number of volatile metabolites were identified in the aerial extracts of wild type and transformed $A$. bracteosa lines using GC-MS analysis. The 97 identified components classified into 7 distinct groups, along with their retention time (RT), molecular formula, molecular weight, and differential peak areas (\%) are given in Table 1. Overall, ABRL3 line had the highest concentration of various metabolites compared to control (wild type). These inferences correspond to relatively higher gene expression in ABRL3.

Mass spectra of many metabolites were consistent with earlier literature regarding $A$. bracteosa (Ali et al., 2018; Ganaie et al., 2016). Many studies suggested the diverse and pronounced biological activities of these metabolites in this plant, e.g., antibacterial (Ganaie et al., 2017); antidiabetic (Hafeez et al., 2017); antioxidant, antiinflammatory, analgesic, antidepressant, and anticoagulant (Kayani et al., 2016c); and hepatoprotective (Hsieh et al., 2011) properties.

\subsubsection{Principal component analysis (PCA)}

Principal component analysis (PCA) is a multivariate statistical technique that aims to explain the variability in a data set without losing important information (Kilimann et al., 2006). In this study, the extent of similarities or differences between wild type and three transgenic lines was evaluated by PCA based on the peak area of 26 selected metabolites (peak area $\geq 2$ ). Principal component analysis identified three significant components; PC 1 explained $87.69 \%$ of the variance, while PC 2 had a variation of $7.94 \%$.

The loading plot of PC 1 was dominated by 13-docosenamide, (Z)-; 2-allyl-5-t-butylhydroquinone, 5; 8-dimethoxy-4-(2-nitrophenyl)-2(1H)-quinolinone; and heptacosane, 1-octadecene (CAS). Only 2 metabolites (cyclohexane, 1, 2, 4-trimethyl- and 3, 5-dimethyldodecane) depicted negative loading values (Figure 4a). The results presented in Figure $4 \mathrm{~b}$ show that PC 2 was mainly contributed by 1-octadecene (CAS); 2,6-undecadienoic acid; 7-ethyl-3-methyl-methyl-ester; and methoxyacetic acid, whereas 8 metabolites including heptacosane had negative loading values.

The combination of PC 1 and PC 2 separated the four employed samples into distinct regions (Figure 4c), which indicated that significant discrimination of metabolites did exist in all samples. Samples with similar characteristics (ABRL1 and ABRL2) had nearby points on the graph, while WT and ABRL3 had the most distant relationship, confirming that metabolic composition is extremely variable between these two lines. Biplot pointed to a clear association among different lines of A. bracteos $a$ and their metabolic profiles (Figure 4d). This interrelationship was further supported by hierarchical analysis (Figure 4e).

\subsection{Abiotic stress tolerance and photosynthetic indices} of the transgenic $A$. bracteosa lines

Although a plethora of salts are found in the soil, $\mathrm{NaCl}$ is considered the principal source of salinization (Shavrukov, 2013). Furthermore, mannitol, an effective osmotic agent, has been reported to mimic in vitro drought stress conditions in plants (Jolayemi and Opabode, 2018). Transgenic leaves fared better than the control, untransformed leaves under multiple stresses (Supplementary Figures $1 \mathrm{a}$ and $1 \mathrm{~b}$ ). We observed that the transgenic leaves tolerated extreme drought and salt stress without visible signs of chlorosis. However, untransformed leaves showed signs of wilting at a drought stress of $100 \mathrm{mM}$ mannitol and exhibited severe chlorosis with increased concentrations of $\mathrm{NaCl}$ (above $50 \mathrm{mM}$ ). These results are in agreement with previous findings that suggested salt and drought stress hamper plant growth and development (Ali and Ismail, 2014; Niazian et al., 2019). Nevertheless, the transgenic leaves survived extreme stress conditions due to the overexpression of rol genes and the production of stress-tolerant metabolites, as supported by previous reports (Bulgakov et al., 2012; Kayani et al., 2016a, 2017).

\subsubsection{Total chlorophyll content}

Salinity and drought can decrease the photosynthetic capacity of plants either due to stomatal closure or through direct damage to photosynthetic machinery (Mittler, 2006). In this study all leaves (control and transgenic) had the highest chlorophyll content under nonstress conditions. After 21 days, a significant difference $(\mathrm{P}<$ 0.001) was observed in total chlorophyll contents between control and transgenic leaves at higher concentrations of mannitol and $\mathrm{NaCl}$. Under drought stress, control leaves had maximum chlorophyll $\left(18.13 \mu \mathrm{mole} / \mathrm{m}^{2}\right)$ at $100 \mathrm{mM}$ mannitol and minimum $\left(10.88 \mu \mathrm{mole} / \mathrm{m}^{2}\right)$ at $400 \mathrm{mM}$ mannitol. A similar pattern was observed under salt stress; control plant leaves had the highest chlorophyll $\left(23.06 \mu \mathrm{mole} / \mathrm{m}^{2}\right)$ at $50 \mathrm{mM} \mathrm{NaCl}$ and lowest $(3.8 \mu$ mole/ $\left.\mathrm{m}^{2}\right)$ at $200 \mathrm{mM}$. Among the transgenic lines, maximum chlorophyll content $\left(17.66 \mu \mathrm{mole} / \mathrm{m}^{2}\right)$ was noted in ABRL2 under extreme drought stress ( $400 \mathrm{mM}$ mannitol), followed by ABRL3 $\left(15.75 \mu \mathrm{mole} / \mathrm{m}^{2}\right)$, and ABRL1 (13.54 $\left.\mu \mathrm{mole} / \mathrm{m}^{2}\right)$. ABRL3 leaves had the highest chlorophyll content $\left(21 \mu \mathrm{mole} / \mathrm{m}^{2}\right)$ at maximum salt stress $(200 \mathrm{mM}$ $\mathrm{NaCl})$, while ABRL1 had the lowest $\left(8.13 \mu \mathrm{mole} / \mathrm{m}^{2}\right)$ chlorophyll content at this concentration.

These results showed that there was a clearer impact of 

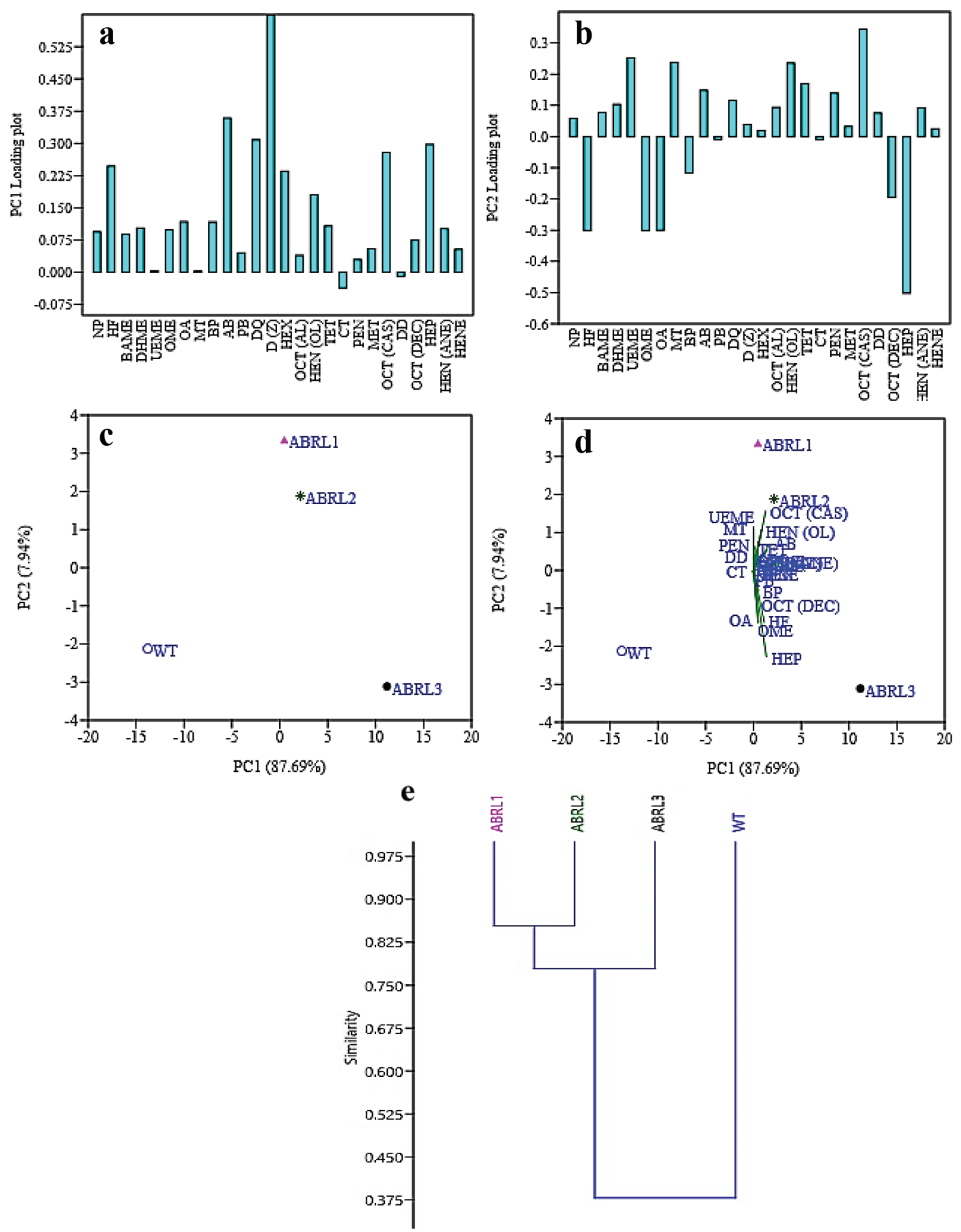

Figure 4. Principal component analysis (PCA) of GC-MS data from samples of Ajuga bracteosa. a: Loading plot of PC 1. b: Loading plot of PC 2. c: Scatter plot of samples in PC 1 vs PC 2. d: Scatter plot of metabolites in PC 1 vs PC 2 (Biplot). e: Relationship between samples based on relative content of metabolites by paired group analysis. $\mathrm{NP}=$ Neophytadiene, $\mathrm{HF}=1-\mathrm{Heneicosyl}$ formate, $\mathrm{BAME}=$ (2S,4S,6S)-(6-Benzenesulfonyl-4-methoxytetrahydropyran-2-yl)acetic acid methyl ester, DHME = 4,5-Dimethoxy-3-hydroxybenzoic acid methyl ester, UEME = 2,6-Undecadienoic acid, 7-ethyl-3-methyl-methyl-ester, OME = 912 15-octadecatrienoic acid methyl ester, $\mathrm{OA}=$ Octadecanoic acid, MT = Methoxyacetic acid, 3-tetradecyl, BP = Bis(2-ethylhexyl) phthalate, AB = 2-Allyl-5-t-butylhydroquinone, $\mathrm{PB}=$ Phenol 2 4-bis(1 1-dimethylethyl), DQ = 5,8-Dimethoxy-4-(2-nitrophenyl)-2(1H)-quinolinone, D (Z) = 13-Docosenamide, (Z)-, HEX = 1-Hexadecanol (CAS), OCT (AL) = Octadecanal, HEN $(\mathrm{OL})=1$-Heneicosanol, TET = n-Tetracosanol-1, CT = Cyclohexane, 1,2,4-trimethyl-, PEN = Pentadecane, MET = 10-Methylnonadecane, OCT (CAS) = 1-Octadecene (CAS), DD = 3,5-Dimethyldodecane, OCT $($ DEC $)=$ Octadecane, HEP = Heptacosane, HEN $($ ANE $)=$ Heneicosane, HENE = Heneicosane, 11 - $(1$-ethylpropyl $)$-, WT = Tissue cultured untransformed line, ABRL1, 2, 3 = A. bracteosa transformed regenerants line 1, 2 and 3. 
drought and salt stress on the chlorophyll content of wild A. bracteosa than in the transformed plants (Figures $5 \mathrm{a}$ and $5 b)$. These findings are supported by Bettini et al. (2016a) who reported that rolB is involved in the overexpression of 5 genes related to photosynthetic activity in transformed tomato plants. More recently, Bettini et al. (2020) further confirmed the role rolB plays in the photoprotection of transgenic tomato through improvement in chlorophyll $\mathrm{a}, \mathrm{b}$, and $\mathrm{a} / \mathrm{b}$ ratios under white light, as compared with control plants.

\subsubsection{Photosynthetic fluorescence parameters}

The two photosynthetic parameters $F_{\sqrt{ }} / F_{\mathrm{m}}$ and $\mathrm{PI}_{\text {(abs) }}$ are considered sensitive indexes of photosystems I and II that can evaluate plant photosynthetic status under stressful conditions (Živčák et al., 2008). Previous studies have shown that when the $F_{\mathrm{v}} / F_{\mathrm{m}}$ value is $0.79-0.83$, the plant is healthy, and its photosynthetic apparatus is not damaged (Baker, 2008).

Tables 2 and 3 show that both $F_{\sqrt{ }} / F_{\mathrm{m}}$ and $\mathrm{PI}_{\text {(abs) }}$ were influenced by stress in $A$. bracteosa. In this study, the $F_{\mathrm{v}} / F_{\mathrm{m}}$ and $\mathrm{PI}_{\text {(abs) }}$ values $(0.80 \pm 0.04$ and $1.80 \pm 0.5$, respectively) were constant in all leaves (control and transgenic) when measured under nonstress conditions. However, both parameters decreased with an increase in stress, which is in line with results previously reported from different species (Maghsoudi et al., 2015). We found
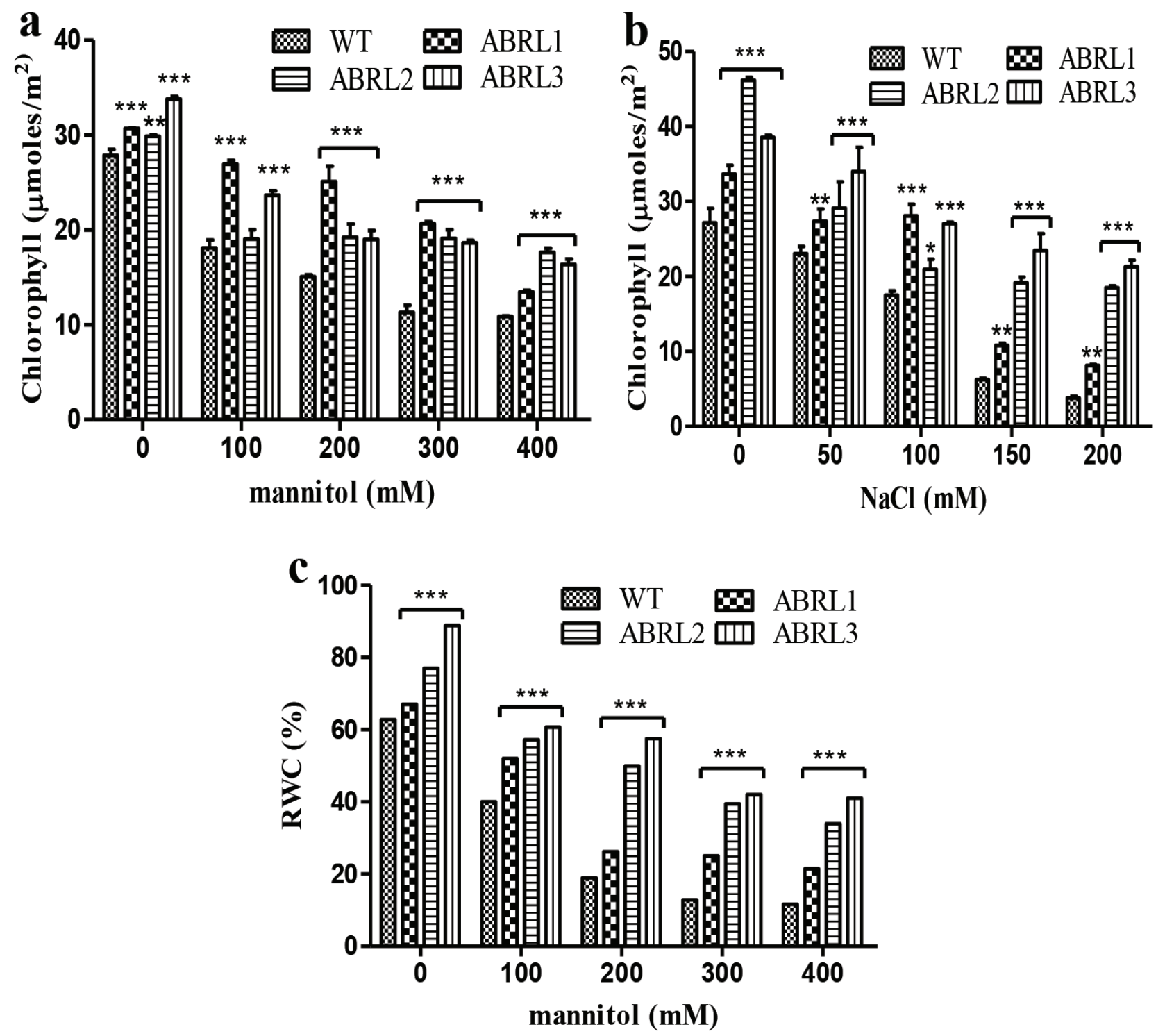

Figure 5. Effect of abiotic stress on chlorophyll and water content of Ajuga bracteosa. Graphs showing comparison of chlorophyll content in a: Drought stress. b: salinity stress. c: Relative water content (RWC) of drought stressed leaves. WT $=$ Tissue cultured untransformed line, ABRL1, 2, $3=$ A. bracteosa regenerants line 1, 2 and 3. Data are expressed as mean \pm S.D. $\left({ }^{\star} \mathrm{P}<0.05,{ }^{* *} \mathrm{P}<0.01,{ }^{* *} \mathrm{P}<0.001\right)$. 
Table 2. Effect of drought stress on fluorescence parameters in Ajuga bracteosa.

\begin{tabular}{|c|c|c|c|c|c|c|c|c|}
\hline Treatment & \multirow{2}{*}{\multicolumn{2}{|c|}{$\begin{array}{l}\text { Untransformed plants } \\
\text { WT }\end{array}$}} & \multicolumn{6}{|c|}{ Transformed plants } \\
\hline \multirow{3}{*}{$\begin{array}{l}\text { Mannitol } \\
(\mathrm{mM})\end{array}$} & & & ABRL1 & & ABRL2 & & ABRL3 & \\
\hline & \multicolumn{2}{|c|}{$\left(3500 \mu \mathrm{m} \mathrm{m}^{-2} \mathrm{~s}^{-1}\right)$} & \multicolumn{2}{|c|}{$\left(3500 \mu \mathrm{m} \mathrm{m}^{-2} \mathrm{~s}^{-1}\right)$} & \multicolumn{2}{|c|}{$\left(3500 \mu \mathrm{m} \mathrm{m}^{-2} \mathrm{~s}^{-1}\right)$} & \multicolumn{2}{|c|}{$\left(3500 \mu \mathrm{m} \mathrm{m}^{-2} \mathrm{~s}^{-1}\right)$} \\
\hline & $F_{v} / F_{\mathrm{m}}$ & $\mathrm{PI}_{(\mathrm{abs})}$ & $F_{v} / F_{\mathrm{m}}$ & $\mathrm{PI}_{\text {(abs) }}$ & $F_{v} / F_{\mathrm{m}}$ & $P I_{(a b s)}$ & $F_{v} / F_{\mathrm{m}}$ & $\mathrm{PI}_{(\mathrm{abs})}$ \\
\hline 0 & $0.79 \pm 0.2$ & $1.59 \pm 0.3$ & $0.80 \pm 0.2$ & $1.80 \pm 0.5$ & $0.81 \pm 0.3$ & $1.77 \pm 0.5$ & $0.82 \pm 0.2$ & $1.84 \pm 0.2$ \\
\hline 100 & $0.62 \pm 0.1$ & $0.79 \pm 0.1$ & $0.78 \pm 0.3$ & $1.45 \pm 0.2$ & $0.77 \pm 0.5$ & $1.36 \pm 0.1$ & $0.80 \pm 0.1$ & $1.57 \pm 0.3$ \\
\hline 200 & $0.32 \pm 0.3$ & $0.15 \pm 0.2$ & $0.73 \pm 0.1$ & $1.39 \pm 0.1$ & $0.66 \pm 0.1$ & $1.27 \pm 0.2$ & $0.77 \pm 0.1$ & $1.3 \pm 0.01$ \\
\hline 300 & $0.27 \pm 0.1$ & $0.12 \pm 0.3$ & $0.72 \pm 0.3$ & $1.35 \pm 0.2$ & $0.64 \pm 0.3$ & $1.28 \pm 0.1$ & $0.69 \pm 0.1$ & $0.83 \pm 0.2$ \\
\hline 400 & $0.21 \pm 0.1$ & $0.10 \pm 0.1$ & $0.70 \pm 0.3$ & $1.36 \pm 0.1$ & $0.63 \pm 0.5$ & $0.96 \pm 0.1$ & $0.64 \pm 0.2$ & $0.69 \pm 0.1$ \\
\hline
\end{tabular}

$\mathrm{WT}=$ Tissue cultured untransformed line, ABRL1, 2, $3=$ A. bracteosa transformed regenerants line 1,2 and $3, F_{v} / F_{\mathrm{m}}=$ Ratio of variable to maximum fluorescence, $\mathrm{PI}_{(\mathrm{abs})}=$ Performance index. Values are means of 3-6 repeated observations $\pm \mathrm{SE}$.

Table 3. Effect of salinity stress on fluorescence parameters in Ajuga bracteosa.

\begin{tabular}{|c|c|c|c|c|c|c|c|c|}
\hline Treatment & \multirow{2}{*}{\multicolumn{2}{|c|}{$\begin{array}{l}\text { Untransformed plants } \\
\text { WT }\end{array}$}} & \multicolumn{6}{|c|}{ Transformed } \\
\hline \multirow{3}{*}{$\mathrm{NaCl}(\mathrm{mM})$} & & & ABRL1 & & ABRL2 & & ABRL3 & \\
\hline & \multicolumn{2}{|c|}{$\left(3500 \mu \mathrm{m} \mathrm{m}^{-2} \mathrm{~s}^{-1}\right)$} & \multicolumn{2}{|c|}{$\left(3500 \mu \mathrm{m} \mathrm{m}^{-2} \mathrm{~s}^{-1}\right)$} & \multicolumn{2}{|c|}{$\left(3500 \mu \mathrm{m} \mathrm{m}^{-2} \mathrm{~s}^{-1}\right)$} & \multicolumn{2}{|c|}{$\left(3500 \mu \mathrm{m} \mathrm{m}^{-2} \mathrm{~s}^{-1}\right)$} \\
\hline & $F_{v} / F_{\mathrm{m}}$ & $\mathrm{PI}_{(\mathrm{abs})}$ & $F_{v} / F_{\mathrm{m}}$ & $\mathrm{PI}_{(\mathrm{abs})}$ & $F_{v} / F_{\mathrm{m}}$ & $\mathrm{PI}_{(\mathrm{abs})}$ & $F_{v} / F_{\mathrm{m}}$ & $\mathrm{PI}_{(\mathrm{abs})}$ \\
\hline 0 & $0.77 \pm 0.1$ & $1.77 \pm 0.1$ & $0.78 \pm 0.3$ & $1.76 \pm 0.3$ & $0.79 \pm 0.1$ & $1.77 \pm 0.3$ & $0.82 \pm 0.2$ & $2.19 \pm 0.1$ \\
\hline 50 & $0.72 \pm 0.1$ & $0.94 \pm 0.3$ & $0.76 \pm 0.1$ & $1.55 \pm 0.5$ & $0.75 \pm 0.3$ & $1.52 \pm 0.1$ & $0.71 \pm 0.1$ & $0.94 \pm 0.2$ \\
\hline 100 & $0.21 \pm 0.2$ & $0.18 \pm 0.5$ & $0.67 \pm 0.3$ & $1.42 \pm 0.1$ & $0.74 \pm 0.3$ & $1.51 \pm 0.5$ & $0.68 \pm 0.3$ & $0.79 \pm 0.1$ \\
\hline 150 & $0.18 \pm 0.3$ & $0.15 \pm 0.1$ & $0.32 \pm 0.1$ & $0.27 \pm 0.1$ & $0.72 \pm 0.1$ & $1.18 \pm 0.1$ & $0.52 \pm 0.1$ & $0.77 \pm 0.5$ \\
\hline 200 & $0.17 \pm 0.3$ & $0.14 \pm 0.1$ & $0.28 \pm 0.3$ & $0.23 \pm 0.2$ & $0.72 \pm 0.1$ & $1.12 \pm 0.1$ & $0.38 \pm 0.1$ & $0.43 \pm 0.1$ \\
\hline
\end{tabular}

$\mathrm{WT}=$ Tissue cultured untransformed line, ABRL1, 2, $3=$ A. bracteosa transformed regenerants line 1,2 and $3, F_{v} / F_{\mathrm{m}}=$ Ratio of variable to maximum fluorescence, $\mathrm{PI}_{(\mathrm{abs})}=\mathrm{P}$ erformance index. Values are means of 3-6 repeated observations $\pm \mathrm{SE}$.

that transgenic lines had comparatively higher $F_{\sqrt{ }} / F_{\mathrm{m}}$ and $\mathrm{PI}_{(\text {abs }}$ values which could be correlated to the expression of rolABC. Our observations are supported by different pieces of evidence that show the interaction of $\mathrm{rolB}$ with photosynthetic parameters. Many reports have suggested that rolB is involved in the photoprotection of PSII through overexpression of cytochrome b6/f complex and carbonic anhydrase in transgenic tomato, as illustrated by improved nonphotochemical quenching parameters, including $F_{\mathrm{v}} / F_{\mathrm{m}}$ (Bettini et al., 2016a, 2020).

While comparing the rate of change in $F_{\mathrm{v}} / F_{\mathrm{m}}$ and $\mathrm{PI}_{(\mathrm{abs})}$ values in 4 lines of $A$. bracteosa we found that $\mathrm{PI}_{(\mathrm{abs})}$ changed greatly in WT under salt and drought stress. These results are consistent with Li et al. (2019) who also found $\mathrm{PI}_{\text {(abs) }}$ to be more sensitive than $F_{v} / F_{\text {m }}$.

\subsection{Relative water content (RWC) under drought stress}

Relative water content is an important variable used to evaluate the metabolic activity, physiological water status, and survival of plants under water deficit (Hasheminasab et al., 2014). In the present study, transgenic leaves had significantly higher $(\mathrm{P}<0.001)$ RWC compared to the wild leaves under drought (Figure $5 \mathrm{c}$ ). Under extreme drought conditions (400 mM mannitol) ABRL3 had maximum RWC (41\%), followed by ABRL2 (33.9\%), ABRL1 (21.4\%), and WT leaves (11.6\%). It has been indicated by different researchers that drought stress reduces RWC in many Lamiaceae species (García-Caparrós et al., 2019). The retention of RWC in transgenic A. bracteosa could also be related to the expression rol genes. Pavlova et al. (2014) found that $r o l$ genes increased the proline synthesis that 
maintains the hydration layer of leaves under drought stress. The accumulation of nitrogenous compounds, including proline, has been frequently reported in plants under drought stress (Bayat and Moghadam, 2019). Similarly, Shahid et al. (2014) found that exogenous application of proline on stressed pea plants improved photosynthetic activity and RWC by regulating guard cells and stomatal closure. Therefore, plants with higher proline content are more resistant to stress conditions.

3.6. Increased level of ROS enzymes in transgenic lines

Plants have developed various antioxidant systems (both enzymatic and nonenzymatic) against ROS to prevent oxidative stress. The major elements of the nonenzymatic antioxidant systems include ascorbic acid, alkaloids, flavonoids, phenolics, GSH, a-tocopherol, and carotenoids. The enzymatic antioxidant system involves superoxide dismutase, ascorbate peroxidase, catalase, glutathione peroxidase, etc. (Sofo et al., 2015). In the current study, we found that catalase (Figures $6 \mathrm{a}$ and $6 \mathrm{~b}$ ) and peroxidase (Figures $6 \mathrm{c}$ and $6 \mathrm{~d}$ ) enzyme activities gradually decreased in the leaves of both transgenic and control plants. However, transgenic leaves followed the same pattern as chlorophyll content, photosynthetic parameters, and RWC, displaying higher catalase and peroxidase activities even in extreme stress conditions. This pattern of catalase and guaiacol peroxidase enzyme activity is consistent with wild and transformed Arabidopsis under salt and drought stress (Manuka et al., 2019). A similar trend was followed by ROS enzymes in tomato plants under multiple stresses (Waseem and Li, 2019).

In general, we found that catalase and peroxidase enzyme activities were at a maximum in ABRL3 under

\section{a}

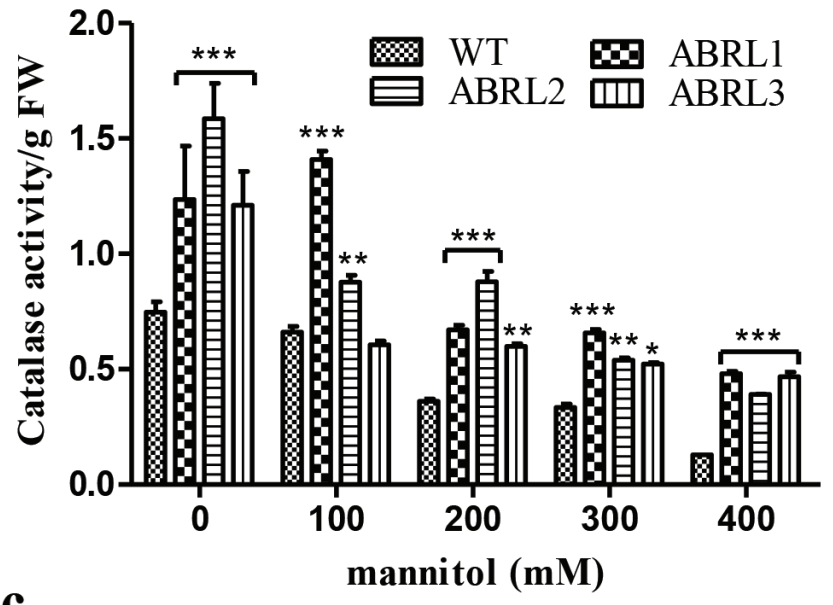

c

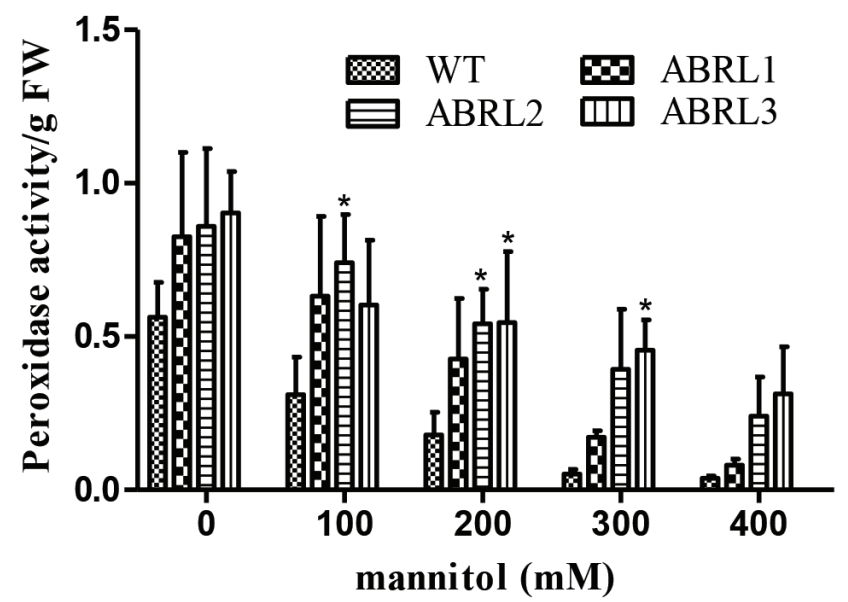

b

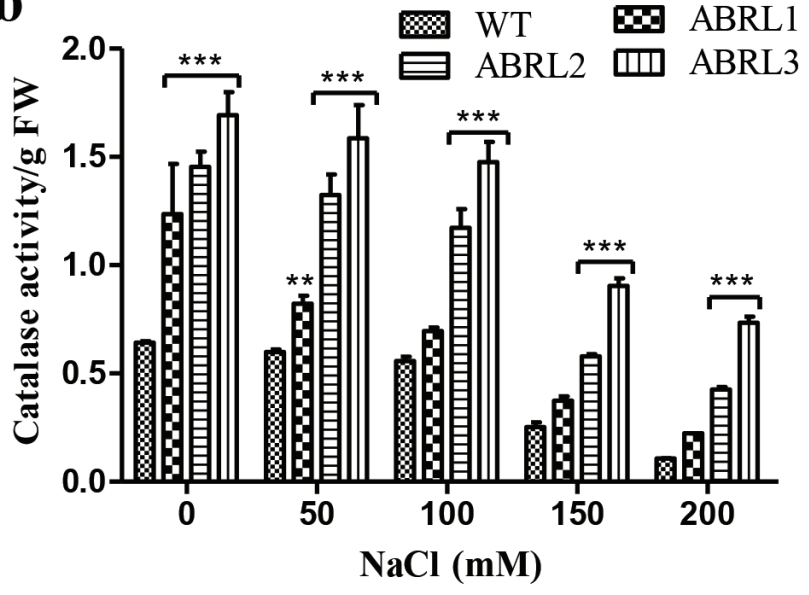

d

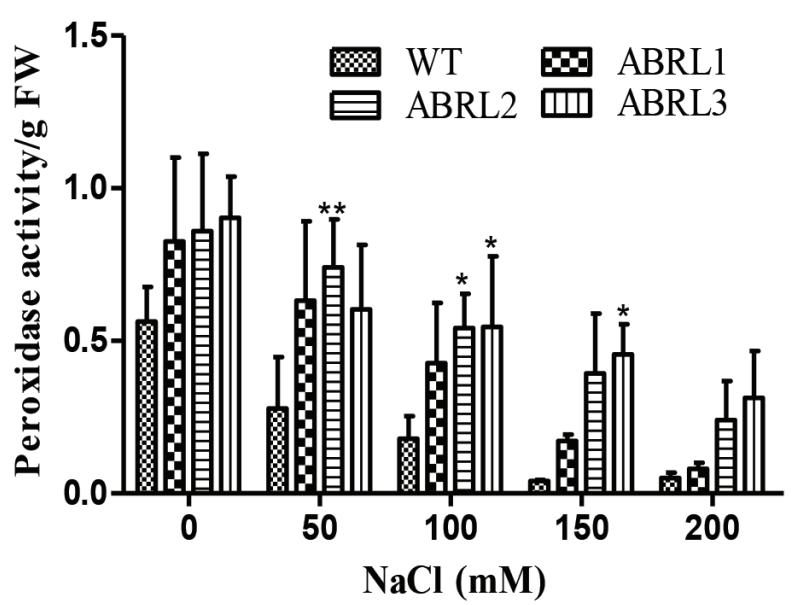

Figure 6. Catalase and peroxidase contents in transgenic Ajuga bracteosa leaves under abiotic stress in comparison with control. a: Catalase activity/g FW under drought stress. b: Catalase activity/g FW under salinity. c: Peroxidase activity/g FW under drought stress. d: Peroxidase activity/g FW under salinity. WT $=$ Tissue cultured untransformed line, ABRL1, 2, $3=$ A. bracteosa transformed regenerants line 1, 2 and 3, FW $=$ Fresh weight. Data are expressed as mean \pm S.D. $\left({ }^{*} \mathrm{P}<0.05,{ }^{* *} \mathrm{P}<0.01,{ }^{* *} \mathrm{P}<0.001\right)$. 

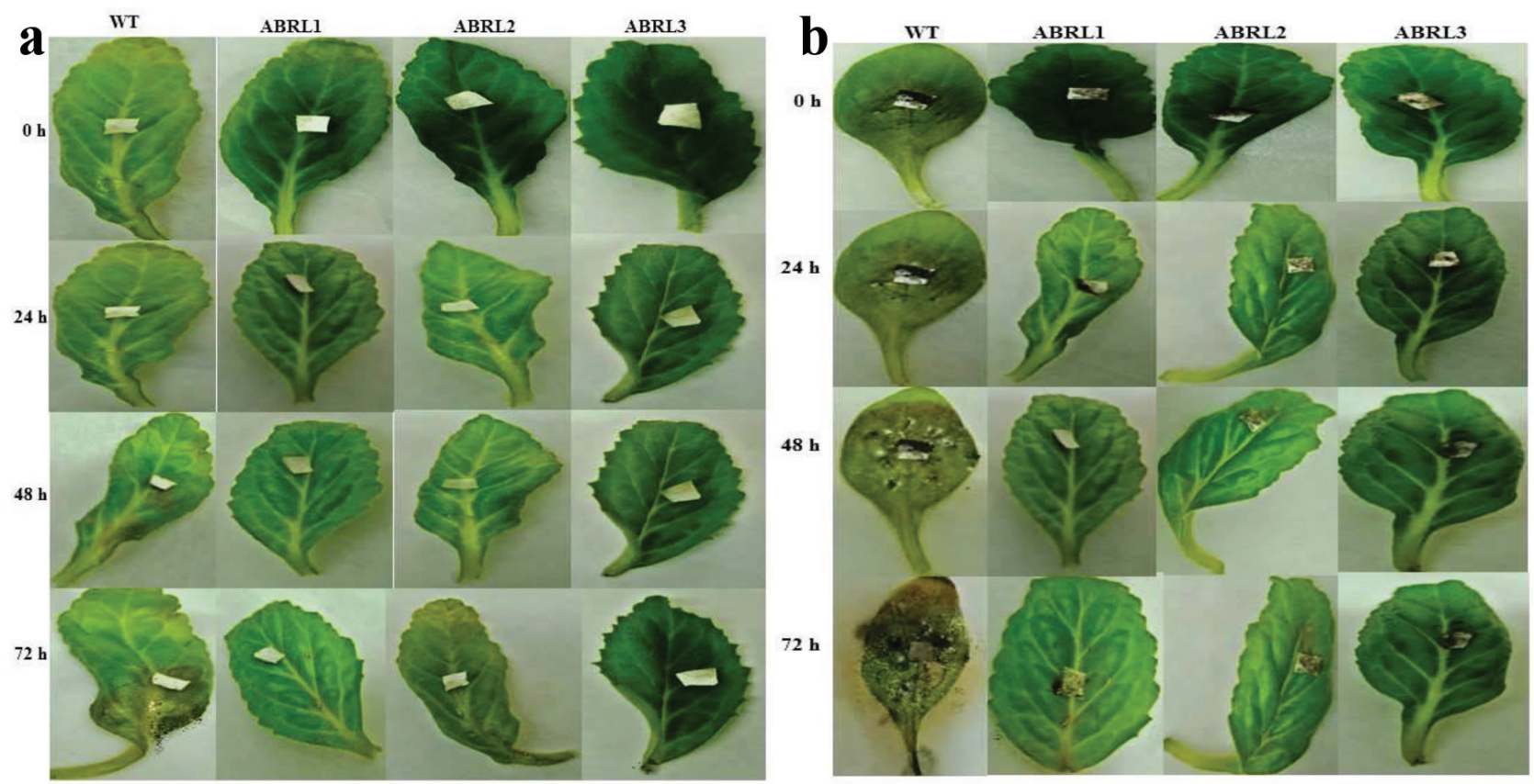

WT

ABRL3

WT

ABRL3
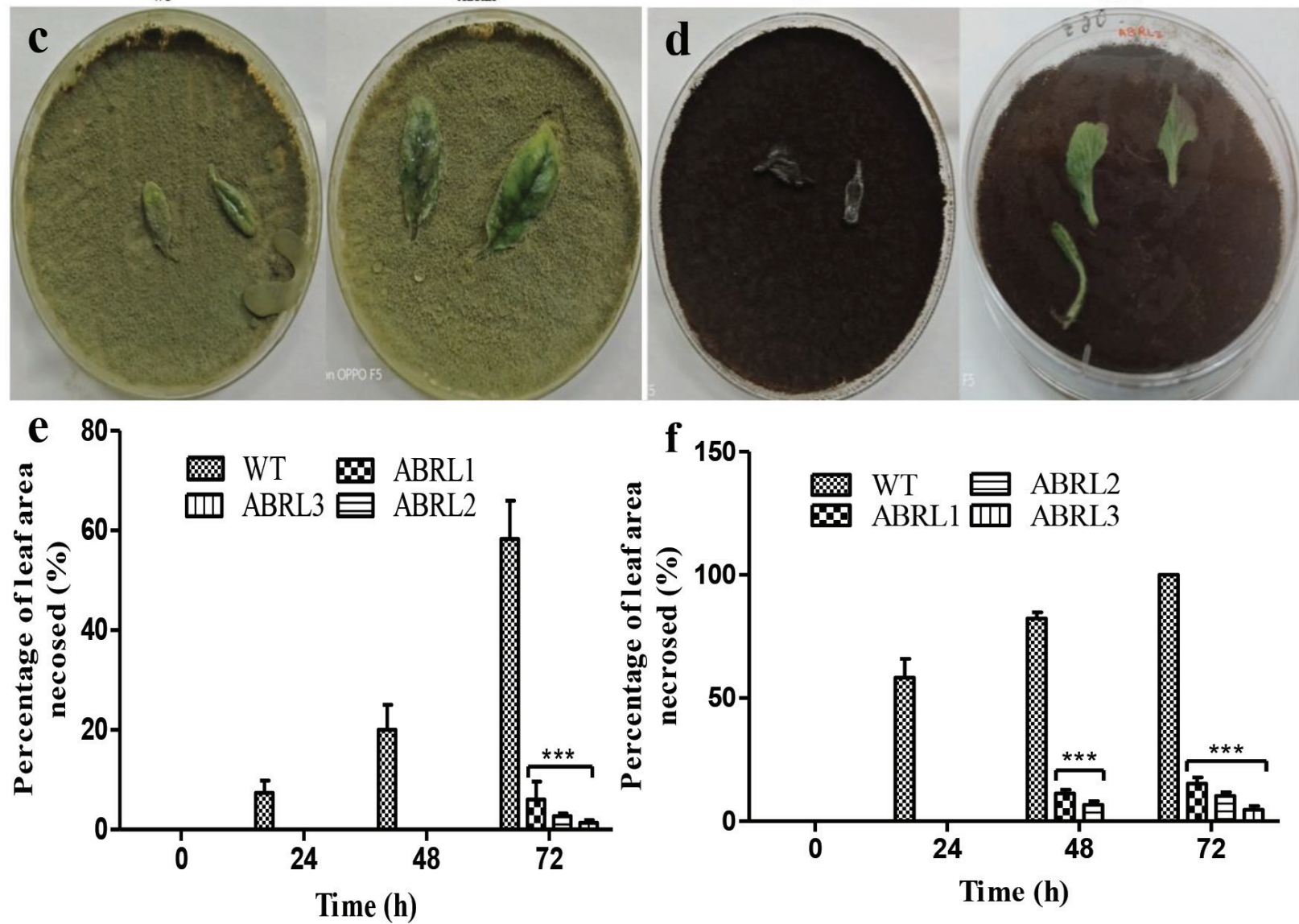

Figure 7. Enhanced fungal resistance in Ajuga bracteosa against Aspergillus fumigatus and Fusarium solani. Leaves inoculated with micelial discs of a: A. fumigatus b: F. solani c: Detached leaf assay against A. fumigatus d: F. solani. e: Graph showing percent leaf area necroted with A. fumigatus. f: Percent leaf area necroted with F. solani. WT $=$ Tissue cultured untransformed line, ABRL1, $2,3=A$. bracteosa transformed regenerants line 1,2 and 3. Data are expressed as mean \pm S.D. $\left({ }^{* * * P}<0.001\right)$. 
extreme stresses and at a minimum in control leaves. Bulgakov et al. (2012) found that $r o l B$ increased the expression of genes encoding for ascorbate peroxidase, catalase, and superoxide dismutase which lead to stress tolerance and ROS scavenging in Arabidopsis thaliana, Panax ginseng, and Rubia cordifolia. Similarly, Dilshad et al. $(2015,2016)$ reported increased synthesis of flavonoids and antioxidant potential in Artemisia species expressing rolB and $C$ genes. Flavonoids scavenge free radicals and remove superoxide and peroxide thus improving plant tolerance to salt and drought stress.

The results of the current study are supported by our previous reports indicating significantly increased production of phytoecdysteroids in rolABC-transformed hairy roots and intact plants of $A$. bracteosa (Kayani et al., 2016a, 2017) which could account for the increased antioxidant activities of this plant.

\subsection{Fungal resistance in transgenic lines}

In the current study, we also get an insight into the effect of rolABC on fungal resistance. We found that the expression of rolABC genes in A. bracteosa conferred resistance against two drug-resistant pathogens. Transgenic leaves had restricted necrotic zone symptoms, while control leaves were completely necrotized by $A$. fumigatus and $F$. solani (Figures $7 \mathrm{a}-7 \mathrm{~d}$ ). Moreover, the percentage of leaf area infected by $A$. fumigatus and $F$. solani was significantly lower in transgenic lines compared to control (Figures $7 \mathrm{e}$ and $7 \mathrm{f}$ ). The aforementioned antifungal resistance can be ascribed to the increased levels of metabolites in transgenic lines, as reported by Özçelik et al. (2011). Likewise, Sánchez-Maldonado et al. (2016) reported the

\section{References}

Aebi H (1984). Catalase in vitro. Methods in Enzymology 105: 121126. doi: 10.1016/S0076-6879(84)05016-3

Ahmad P, Ashraf M, Younis M, Hu X, Kumar A et al. (2012). Role of transgenic plants in agriculture and biopharming. Biotechnology Advances 30 (3): 524-540. doi: 10.1016/j. biotechadv.2011.09.006

Airoldi CA, Hearn TJ, Brockington SF (2019). TTG1 proteins regulate circadian activity as well as epidermal cell fate and pigmentation. Nature Plants 5 (11): 1145-1153. doi: 10.1038/ s41477-019-0544-3

Ali HEM, Ismail GSM (2014). Tomato fruit quality as influenced by salinity and nitric oxide. Turkish Journal of Botany 38 (1): 122129. doi: $10.3906 /$ bot-1210-44

Ali H, Khan MA, Kayani WK, Khan T, Khan RS (2018). Thidiazuron regulated growth, secondary metabolism and essential oil profiles in shoot cultures of Ajuga bracteosa. Industrial Crops and Products 121: 418-427. doi: 10.1016/j.indcrop.2018.05.043 antifungal properties of phenolics and glycoalkaloids in potato plants. Similarly, Arshad et al. (2014) reported that rolB gene improved foliar tolerance of transgenic tomato leaves against two pathogenic fungal strains Alternaria solani and Fusarium oxysporum, compared to wild tomato plants. Bettini et al. (2016b) reported that rolA also enhanced the antifungal activities of tomato. Furthermore, Kiani et al. (2019) found higher antifungal resistance in rolABC-transformed Artemisia dubia, suggesting that rol genes modified the phytochemical constituents that are involved in microbial defense in this plant.

In conclusion, this study dissects the effects of rolABC genes on the metabolic pathways in A. bracteosa. The increased expression levels of all genes is in accordance with the accumulation of volatile metabolites as well as biotic and abiotic stress resistance in transformed plants.

\section{Acknowledgments}

We are thankful to Yury N. Shkryl from the Institute of Biology and Soil Science, Russian Academy of Sciences, Russia for providing the bacterial strain of Agrobacterium rhizogenes (LBA-9402). Professor Rosa Cusido and Professor Javier Palazon from the University of Barcelona Spain are acknowledged for providing the facility to generate transgenic hairy root lines.

\section{Contribution of authors}

BM and WKK designed the project, and SR carried out the practical work. RM contributed to GC-MS data analysis. SR wrote the paper, while WKK and BM critically evaluated the manuscript.

Al-Hatmi AMS, De Hoog GS, Meis JF (2019). Multiresistant Fusarium pathogens on plants and humans: solutions in (from) the antifungal pipeline? Infection and Drug Resistance 12: 3727-3737. doi: 10.2147/IDR.S180912

Arndt SK, Irawan A, Sanders GJ (2015). Apoplastic water fraction and rehydration techniques introduce significant errors in measurements of relative water content and osmotic potential in plant leaves. Physiologia Plantarum 155 (4): 355-368. doi: $10.1111 /$ ppl.12380

Arshad W, Ihsan-ul-Haq, Waheed MT, Mysore KS, Mirza B (2014). Agrobacterium-mediated transformation of tomato with rolB gene results in enhancement of fruit quality and foliar resistance against fungal pathogens. PLoS One 9 (5): e96979. doi: 10.1371/journal.pone.0096979

Baker NR (2008). Chlorophyll fluorescence: a probe of photosynthesis in vivo. Annual Review of Plant Biology 59: 89-113. doi: 10.1146/annurev.arplant.59.032607.092759 
Bayat H, Moghadam AN (2019). Drought effects on growth, water status, proline content and antioxidant system in three Salvia nemorosa L. cultivars. Acta Physiologiae Plantarum 41 (9): 149. doi: 10.1007/s11738-019-2942-6

Bettini PP, Marvasi M, Fani F, Lazzara L, Cosi E et al. (2016a). Agrobacterium rhizogenes rolB gene affects photosynthesis and chlorophyll content in transgenic tomato (Solanum lycopersicum L.) plants. Journal of Plant Physiology 204: 27-35. doi: 10.1016/j.jplph.2016.07.010

Bettini PP, Santangelo E, Baraldi R, Rapparini F, Mosconi P et al. (20016b). Agrobacterium rhizogenes rolA gene promotes tolerance to Fusarium oxysporum $\mathrm{f}$. sp. lycopersici in transgenic tomato plants (Solanum lycopersicum L.). Journal of Plant Biochemistry and Biotechnology 25: 225-233. doi: 10.1007/ s13562-015-0328-4

Bettini PP, Lazzara L, Massi L, Fani F, Mauro ML (2020). Effect of farred light exposure on photosynthesis and photoprotection in tomato plants transgenic for the Agrobacterium rhizogenes rolB gene. Journal of Plant Physiology 245: 153095. doi: 10.1016/j. jplph.2019.153095

Bulgakov VP (2008). Functions of rol genes in plant secondary metabolism. Biotechnology Advances 26 (4): 318-324. doi: 10.1016/j.biotechadv.2008.03.001

Bulgakov VP, Gorpenchenko TY, Veremeichik GN, Shkryl YN, Tchernoded GK et al. (2012). The rolB gene suppresses reactive oxygen species in transformed plant cells through the sustained activation of antioxidant defense. Plant Physiology 158 (3): 1371-1381. doi: 10.1104/pp.111.191494

Bulgakov VP, Veremeichik GN, Grigorchuk VP, Rybin VG, Shkryl YN (2016). The rolB gene activates secondary metabolism in Arabidopsis calli via selective activation of genes encoding MYB and bHLH transcription factors. Plant Physiology and Biochemistry 102: 70-79. doi: 10.1016/j.plaphy.2016.02.015

Chance B, Maehly A (1955). Assay of catalases and peroxidases. Methods in Enzymology 2: 764-775. doi: 10.1016/S00766879(55)02300-8

Chen DH, Liu CJ, Ye HC, Li GF, Liu BY et al. (1999). Ri-mediated transformation of Artemisia annua with a recombinant farnesyl diphosphate synthase gene for artemisinin production. Plant Cell and Tissue Organ Culture 57 (3): 157-162. doi: 10.1023/A:1006326818509

Chowdhury S, Basu A, Kundu S (2017). Overexpression of a new osmotin-like protein gene (SindOLP) confers tolerance against biotic and abiotic stresses in sesame. Frontiers in Plant Science 8: 410. doi: 10.3389/fpls.2017.00410

Czarnocka W, Karpiński S (2018). Friend or foe? Reactive oxygen species production, scavenging and signaling in plant response to environmental stresses. Free Radical Biology and Medicine 122: 4-20. doi: 10.1016/j.freeradbiomed.2018.01.011

Dilshad E, Cusido RM, Estrada KR, Bonfill M, Mirza B (2015). Genetic transformation of Artemisia carvifolia Buch with rol genes enhances artemisinin accumulation. PLoS One 10 (10): e0140266. doi: 10.1371/journal.pone.0140266
Dilshad E, Zafar S, Ismail H, Waheed MT, Cusido RM et al. (2016). Effect of rol genes on polyphenols biosynthesis in Artemisia annua and their effect on antioxidant and cytotoxic potential of the plant. Applied Biochemistry and Biotechnology 179 (8): 1456-1468. doi: 10.1007/s12010-016-2077-9

Dubrovina AS, Manyakhin AY, Zhuravlev YN, Kiselev KV (2010). Resveratrol content and expression of phenylalanine ammonialyase and stilbene synthase genes in rolC transgenic cell cultures of Vitis amurensis. Applied Microbiology and Biotechnology 88 (3): 727-736. doi: 10.1007/s00253-010-2792-z

Dudareva N, Klempien A, Muhlemann JK, Kaplan I (2013). Biosynthesis, function and metabolic engineering of plant volatile organic compounds. New Phytologist 198 (1): 16-32. doi: $10.1111 / \mathrm{nph} .12145$

Ganaie HA, Ali MN, Ganai BA (2016). GC-MS analysis and evaluation of mutagenic and antimutagenic activity of ethyl acetate extract of Ajuga bracteosa wall ex. benth: an endemic medicinal plant of Kashmir himalaya, India. Journal of Clinical Toxicology 6: 0495-2161. doi: 10.4172/2161-0495.1000288

Ganaie HA, Ali MN, Ganai BA, Meraj M, Ahmad M (2017). Antibacterial activity of 14, 15-dihydroajugapitin and 8-o-acetylharpagide isolated from Ajuga bracteosa Wall ex. Benth against human pathogenic bacteria. Microbial Pathogenesis 103: 114-118. doi: 10.1016/j.micpath.2016.12.017

García-Caparrós P, Romero MJ, Llanderal A, Cermeño P, Lao MT et al. (2019). Effects of drought stress on biomass, essential oil content, nutritional parameters, and costs of production in six Lamiaceae species. Water 11 (3): 573. doi: 10.3390/w11030573

Hafeez K, Andleeb S, Ghousa T, Rozina GM, Naseer A et al. (2017). Phytochemical screening, alpha-glucosidase inhibition, antibacterial and antioxidant potential of Ajuga bracteosa extracts. Current Pharmaceutical Biotechnology 18 (4): 336342. doi: $10.2174 / 1389201018666170313095033$

Hasheminasab H, Farshadfar E, Varvani H (2014). Application of physiological traits related to plant water status for predicting yield stability in wheat under drought stress condition. Annual Research and Review in Biology 4 (5): 778-789. doi: 10.9734/ ARRB/2014/6689

Hsieh WT, Liu YT, Lin WC (2011). Anti-inflammatory properties of Ajuga bracteosa in vivo and in vitro study and their effects on mouse model of liver fibrosis. Journal of Ethnopharmacology 135 (1):116-125. doi: 10.1016/j.jep.2011.02.031

Isah T, Umar S, Mujib A, Sharma MP, Rajasekharan PE et al. (2018). Secondary metabolism of pharmaceuticals in the plant in vitro cultures: strategies, approaches, and limitations to achieving higher yield. Plant Cell Tissue and Organ Culture 132 (2): 239265. doi: $10.1007 / \mathrm{s} 11240-017-1332-2$

Isah T (2019). Stress and defense responses in plant secondary metabolites production. Biological Research 52 (1): 39. doi: 10.1186/s40659-019-0246-3

Jolayemi OL, Opabode JT (2018). Responses of cassava (Manihot esculenta Crantz) varieties to in vitro mannitol-induced drought stress. Journal of Crop Improvement 32 (4): 566-578. doi: 10.1080/15427528.2018.1471431 
Kayani WK, Palazòn J, Cusidò RM, Mirza B (2016a). The effect of rol genes on phytoecdysteroid biosynthesis in Ajuga bracteosa differs between transgenic plants and hairy roots. RSC Advances 6 (27): 22700-22708. doi: 10.1039/C6RA00250A

Kayani WK, Fattahi M, Palazòn J, Cusidò RM, Mirza B (2016b). Comprehensive screening of influential factors in the Agrobacterium tumefaciens-mediated transformation of the Himalayan elixir: Ajuga bracteosa Wall. ex. Benth. Journal of Applied Research on Medicinal and Aromatic Plants 3 (4): 151-159. doi: 10.1016/j.jarmap.2016.03.002

Kayani WK, Dilshad E, Ahmed T, Ismail H, Mirza B (2016c). Evaluation of Ajuga bracteosa for antioxidant, antiinflammatory, analgesic, antidepressant and anticoagulant activities. BMC Complementary and Alternative Medicine 16 (1): 375. doi: 10.1186/s12906-016-1363-y

Kayani WK, Palazòn J, Cusidò RM, Mirza B (2017). Effect of pRi T-DNA genes and elicitation on morphology and phytoecdysteroid biosynthesis in Ajuga bracteosa hairy roots. RSC Advances 7 (76): 47945-47953. doi: 10.1039/C7RA06399G

Kiani BH, Suberu J, Barker GC, Mirza B (2014). Development of efficient miniprep transformation methods for Artemisia annua using Agrobacterium tumefaciens and Agrobacterium rhizogenes. In Vitro Cellular and Developmental Biology-Plant 50 (5): 590-600. doi: 10.1007/s11627-014-9607-3

Kiani BH, Ullah N, Haq IU, Mirza B (2019). Transgenic Artemisia dubia WALL showed altered phytochemistry and pharmacology. Arabian Journal of Chemistry 12 (8): 26442654. doi: 10.1016/j.arabjc.2015.04.020

Kilimann KV, Hartmann C, Delgado A, Vogel RF, Gänzle MG (2006). Combined high pressure and temperature induced lethal and sublethal injury of Lactococcus lactis-Application of multivariate statistical analysis. International Journal of Food Microbiology 109 (1-2): 25-33. doi: 10.1016/j. ijfoodmicro.2006.01.006

Li Y, Zhang T, Zhang Z, He K (2019). The physiological and biochemical photosynthetic properties of Lycium ruthenicum Murr in response to salinity and drought. Scientia Horticulturae 256: 108530. doi: 10.1016/j.scienta.2019.05.057

Luz AC, Pretti IR, Batitucci M (2016). Comparison of RNA extraction methods for Passiflora edulis sims leaves. Revista Brasileira de Fruticultura 38 (1): 226-232. doi: 10.1590/0100-2945-278/15

Maghsoudi K, Emam Y, Ashraf M (2015). Influence of foliar application of silicon on chlorophyll fluorescence, photosynthetic pigments, and growth in water-stressed wheat cultivars differing in drought tolerance. Turkish Journal of Botany 39 (4): 625-634. doi 10.3906/bot-1407-11

Manuka R, Karle SB, Kumar K (2019). OsWNK9 mitigates salt and drought stress effects through induced antioxidant systems in Arabidopsis. Plant Physiology Reports 24 (2): 168-181. doi: 10.1007/s40502-019-00448-w

Mittler R (2006). Abiotic stress, the field environment and stress combination. Trends in Plant Science 11 (1): 15-19. doi: 10.1016/j.tplants.2005.11.002
Murashige T, Skoog F (1962). A revised medium for rapid growth and bio assays with tobacco tissue cultures. Physiologia Plantarum 15 (3): 473-497. doi: 10.1111/j.1399-3054.1962.tb08052.x

Nayyar H, Gupta D (2006). Differential sensitivity of $\mathrm{C}_{3}$ and $\mathrm{C}_{4}$ plants to water deficit stress: association with oxidative stress and antioxidants. Environmental and Experimental Botany 58 (1-3): 106-113. doi: 10.1016/j.envexpbot.2005.06.021

Netto AT, Campostrini E, de Oliveira JG, Bressan-Smith RE (2005). Photosynthetic pigments, nitrogen, chlorophyll a fluorescence and SPAD-502 readings in coffee leaves. Scientia Horticulturae 104 (2): 199-209. doi: 10.1016/j.scienta.2004.08.013

Niazian M, Sadat-Noori SA, Tohidfar M, Galuszka P, Mortazavian SM (2019). Agrobacterium-mediated genetic transformation of ajowan (Trachyspermum ammi (L.) Sprague): an important industrial medicinal plant. Industrial Crops and Products 132: 29-40. doi: 10.1016/j.indcrop.2019.02.005

Özçelik B, Kartal M, Orhan I (2011). Cytotoxicity, antiviral and antimicrobial activities of alkaloids, flavonoids, and phenolic acids. Pharmaceutical Biology 49 (4): 396-402. doi: $10.3109 / 13880209.2010 .519390$

Park HY, Kim DH, Sivanesan I (2017). Micropropagation of Ajuga species: a mini review. Biotechnology Letters 39: 1291-1298. doi: 10.1007/s10529-017-2376-4

Pavlova OA, Matveyeva TV, Lutova LA (2014), rol-Genes of Agrobacterium rhizogenes. Russian Journal of Genetics: Applied Research 4: 137-145. doi: 10.1134/S2079059714020063

Sánchez-Maldonado AF, Schieber A, Gänzle MG (2016). Antifungal activity of secondary plant metabolites from potatoes (Solanum tuberosum L.): Glycoalkaloids and phenolic acids show synergistic effects. Journal of Applied Microbiology 120 (4): 955-965. doi: 10.1111/jam.13056

Shahid MA, Balal RM, Pervez MA, Abbas T, Aqeel MA et al. (2014). Exogenous proline and proline-enriched Lolium perenne leaf extract protects against phytotoxic effects of nickel and salinity in Pisum sativum by altering polyamine metabolism in leaves. Turkish Journal of Botany 38: 914-26. doi: 10.3906/bot-1312-13

Shavrukov Y (2013). Salt stress or salt shock: which genes are we studying? Journal of Experimental Botany 64 (1): 119-127. doi: $10.1093 / \mathrm{jxb} / \mathrm{ers} 316$

Sofo A, Scopa A, Nuzzaci M, Vitti A (2015). Ascorbate peroxidase and catalase activities and their genetic regulation in plants subjected to drought and salinity stresses. International Journal of Molecular Sciences 16 (6): 13561-13578. doi: 10.3390/ijms160613561

Tanaka N, Matsumoto T (1993). Regenerants from Ajuga hairy roots with high productivity of 20-hydroxyecdysone. Plant Cell Reports 13 (2): 87-90. doi: 10.1007/BF00235296

Waseem M, Li Z (2019). Dissecting the role of a Basic Helix-Loop-Helix transcription factor, SlbHLH22, under salt and drought stresses in transgenic Solanum lycopersicum L. Frontiers in Plant Science 10: 734. doi: 10.3389/fpls.2019.00734

Živčák M, Brestič M, Olšovská K, Slamka P (2008). Performance index as a sensitive indicator of water stress in Triticum aestivum L. Plant, Soil and Environment 54 (4): 133-139. doi: 10.17221/392-PSE 
RUBNAWAZ et al. / Turk J Bot

Supplementary Table 1. List of primer sequences used in this study.

\begin{tabular}{|l|l|}
\hline Genes & Primer sequences \\
\hline rolA-F & AGAATGGAATTAGCCGGACTA \\
\hline rolA-R & GTATTAATCCCGTAGGTTTGTT \\
\hline HMGR-F & TGCTGGTTCTCTTGGTGGAT \\
\hline HMGR-R & CTCCAACTGTGCCAACCTCT \\
\hline FDS-F & GAACTCGCCAATGAGGAACA \\
\hline FDS-R & TTTCAGCACCGCTTGGACT \\
\hline HDS-F & CAAACCATGGGAGCCTTTCG \\
\hline HDS-R & GCAACAAGGAGACGGTATGC \\
\hline PAL-F & AACCTCAACATCACTCCATGC \\
\hline PAL-R & ATTATGGCGGCCGATTC \\
\hline TTG1-F & AATCCCATTCGAGCCCACT \\
\hline TTG1-R & GACTTTGCCTGTTGCGGAG \\
\hline$\beta$-actin- $\mathrm{F}$ & TCTCGATGGAAGAGCTGGTT \\
\hline$\beta$-actin- $\mathrm{R}$ & GATCCTTACCGAGGGAGGTT \\
\hline
\end{tabular}



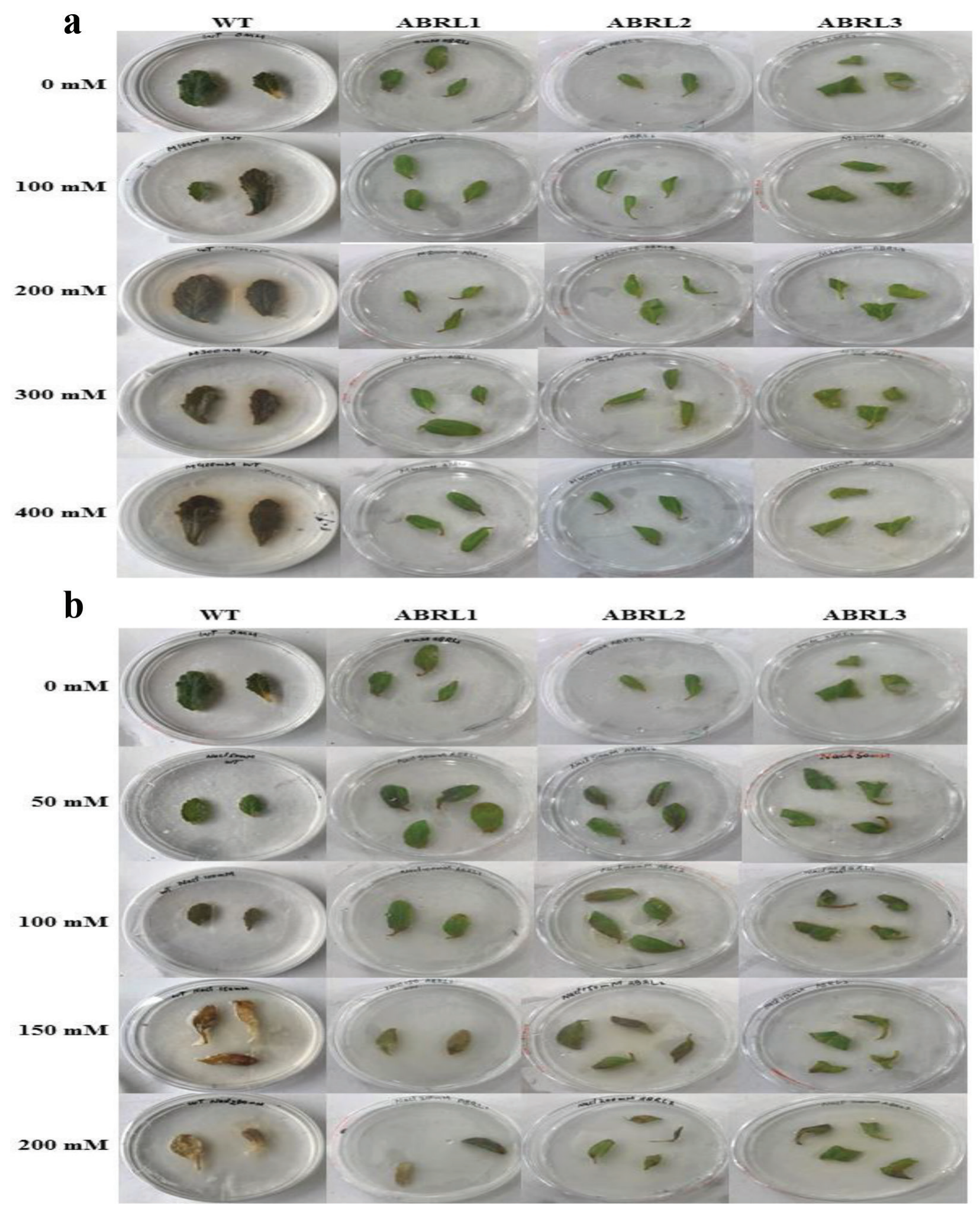

Supplementary Figure 1. Effect of drought and salt stress on Ajuga bracteosa. a: Treatment with different mannitol concentrations. b: Effect of different $\mathrm{NaCl}$ concentrations after 21 days. WT $=$ Tissue cultured untransformed line, ABRL1, 2, $3=$ A. bracteosa regenerants line 1,2 and 3. 